\title{
Fourth grade elementary students' perception of the motivational aspects of using computers to write in the "Student as Authors" Project
}

Karla Ribeiro de Assis

West Virginia University

Follow this and additional works at: https://researchrepository.wvu.edu/etd

\section{Recommended Citation}

Assis, Karla Ribeiro de, "Fourth grade elementary students' perception of the motivational aspects of using computers to write in the "Student as Authors" Project" (2001). Graduate Theses, Dissertations, and Problem Reports. 687.

https://researchrepository.wvu.edu/etd/687

This Thesis is protected by copyright and/or related rights. It has been brought to you by the The Research Repository @ WVU with permission from the rights-holder(s). You are free to use this Thesis in any way that is permitted by the copyright and related rights legislation that applies to your use. For other uses you must obtain permission from the rights-holder(s) directly, unless additional rights are indicated by a Creative Commons license in the record and/ or on the work itself. This Thesis has been accepted for inclusion in WVU Graduate Theses, Dissertations, and Problem Reports collection by an authorized administrator of The Research Repository @ WVU. For more information, please contact researchrepository@mail.wvu.edu. 
Fourth Grade Elementary Students' Perception of the Motivational Aspects of Using Computers to Write in the "Student as Authors" Project

By

Karla R. Assis

Thesis submitted to the

College of Human Resources and Education

at West Virginia University

in partial fulfillment of the requirements

for the degree of

Master of Arts

in

Technology Education

Approved by

George Maughan, Ph.D., Chair

Judy Abbott, Ph.D.

Anita Nedeff, M.A.

Department of Advanced Educational Studies

Morgantown, West Virginia

2001

Keywords: ESL writing, multicultural, writing project, L2 writing Copyright 2001 Karla R. Assis 


\title{
ABSTRACT \\ FOURTH GRADE ELEMENTARY STUDENTS' PERCEPTION OF THE MOTIVATIONAL ASPECTS OF USING COMPUTERS TO WRITE IN THE "STUDENT AS AUTHORS" PROJECT
}

\begin{abstract}
Karla R. Assis
The purpose of this study was to describe fourth grade elementary students' perception of the motivational aspects of using computers to write in the "Student as Authors" Project. The following questions were answered in this research: a) how do fourth grade students perceive the importance of computers in the "Students as Authors" Project? b) what are the motivational aspects of using a computer to write in the "Student as Authors" Project from fourth grade students' perspective? The researcher used questionnaire, and interviews as modes of data collection. This study indicates that students consider computer important in the "Student as Authors" Project. The fun of using a computer to write was considered to be the major motivational aspect of using a computer to write. However, students considered writing on paper and pencil as important as writing on the computer. Further study was recommended.
\end{abstract}


To my mother, Alzenir, the woman whom I most love and admire, To the people who never gave up on me, my brothers, Aleksandro and Rodrigo

To my father, João, who together with my mother, gave me the most worthy present of my life, my education, and to my soul mate, my eternal love, Herval.

Para a mulher que eu mais admiro e amo, minha mãe Alzenir. Para as pessoas que sempre me apoiaram, meus irmãos Aleksandro e Rodrigo. Para meu pai, João, que junto com minha mãe me deu o presente mais valioso do mundo, a minha educação, e para minha alma gêmea, meu eterno amor, Herval. 


\section{ACKNOWLEDGMENTS}

There are a great number of people, who supported me throughout the process of turning this work to reality. To all of my friends and family, although your names do not show up here you know who you are and how important you are to me, my deep gratitude.

Special thanks to the people who believed in me more than I did and who gave me emotional and professional support to overcome barriers and become a better person and a better professional, to you Tracy Dingess, Dara Shaw and Helen Huntley my sincere gratitude. I thank God for having the chance of meeting people like you.

I would like to thank the Department of Foreign Languages, especially Dr. Frank Medley, the West Virginia Intensive English Program students and staff as well as the Computer Language Lab proctors for supporting me during my stay in Morgantown.

To the members of my committee I will never be able to thank you enough. My sincere appreciation and thanks to my committee members Dr. Judy Abbott, who guided me through the rediscovery of the beauty of reading and writing, and Anita Nedeff who helped me to find again the joy and love for teaching. I found in you role models to whom I wish to follow. To the chair of my committee Dr. George Maughan, thanks for not letting me give up and for supporting me in my ups and downs, having sometimes to dry up my tears, your insights and guidance were crucial for the accomplishment of this work.

I would also like to thank Dr. Sandra Dixon for her friendship and support. My gratitude also to my dearest friend Marina Spears who for me is the sister that I did not have, thank you for helping me find my way and supporting me through all the difficult moments.

Finally I would like to thank all the participants of this study without whom this research would never have happened.

Aos meus avós Anna e Antônio Ribeiro, pela sua sabedoria, amor pela vida e pelas pessoas. Agradecimento especial à pessoa que formou as minhas memórias de infância, obrigada vô Francisco Freire, por ter sido um ser humano admirável, pena não ter tido tempo nem maturidade para dizer o quanto te amava. Sua memória sempre fará parte da minha vida. Meus pais, meus irmaos e Herval, obrigada por deixar que os ame, vocês são as pessoas mais importantes de minha vida. 


\section{TABLE OF CONTENTS}

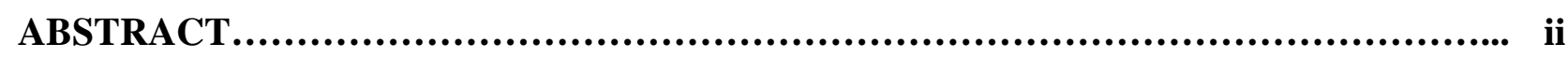

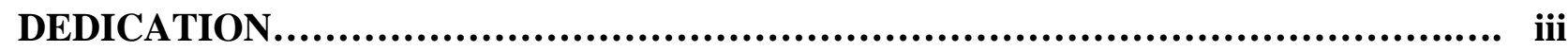

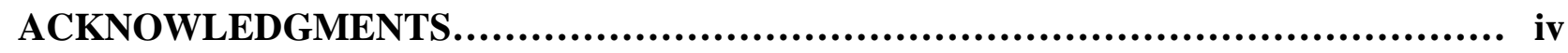

TABLE OF CONTENTS.............................................................. v

LIST OF TABLES..................................................................... vii

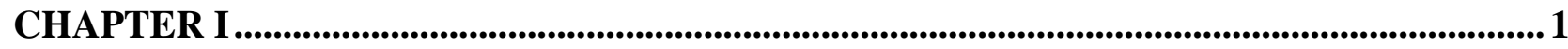

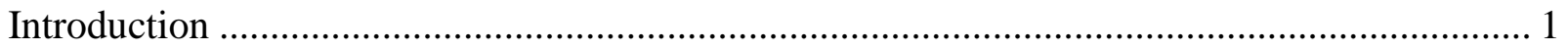

Background for this Research...................................................................................... 4

Using Computers for Writing in Elementary School ............................................................. 4

The Use of Computers to Write by English as a Second Language (ESL) Students ................ 5

Motivational Aspects of Using Computers to Write ................................................................. 6

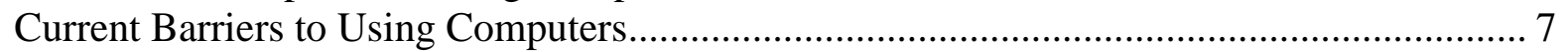

Bald Eagle Elementary School......................................................................................... 7

"Student as Authors" Project.......................................................................................... 9

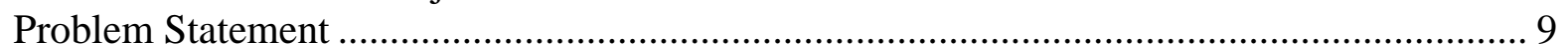

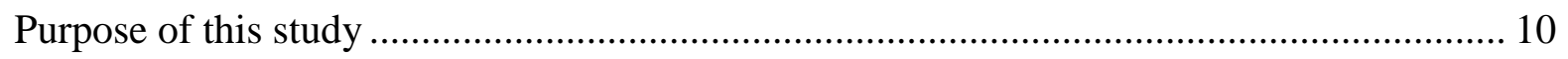

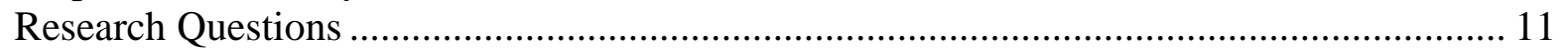

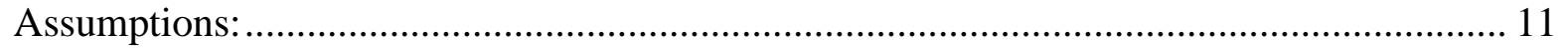

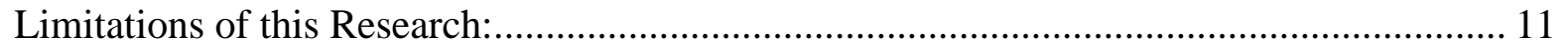

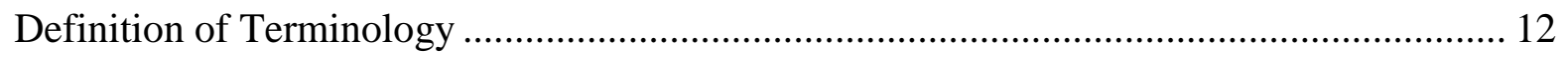

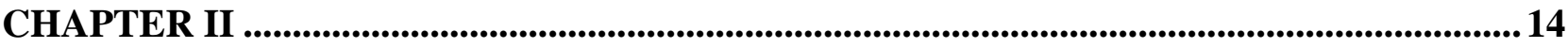

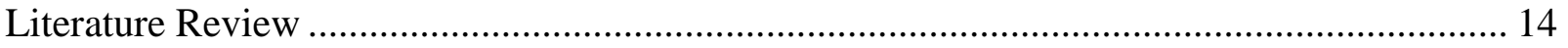

Using Computers to Write in Elementary School................................................................ 15

The Use of Computers to Write by English as a Second Language (ESL) Students ............. 19

Motivational Aspects of Using Computers to Write ............................................................... 23

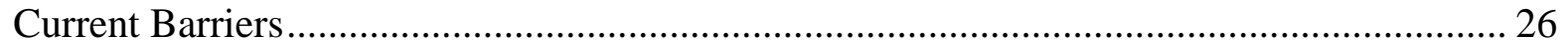

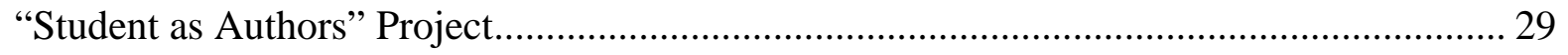

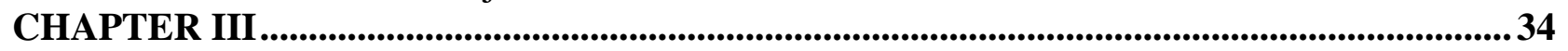

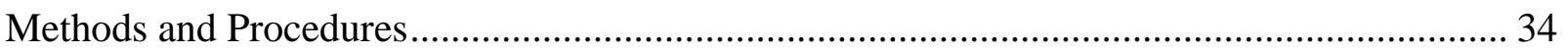

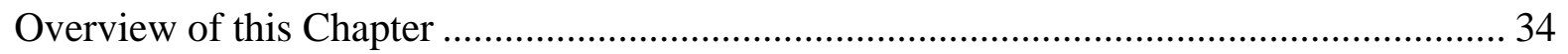

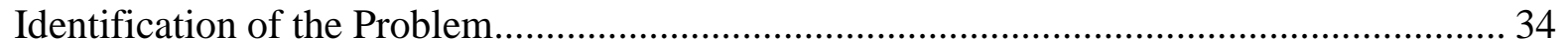

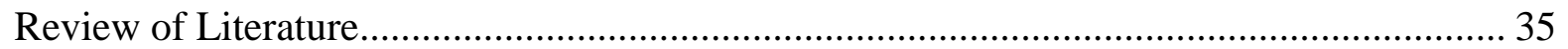

Identification of Participants ....................................................................................... 35

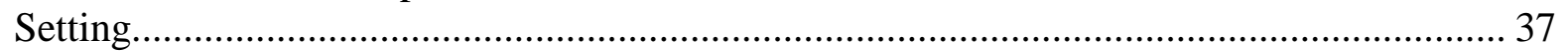

Identification and Creation of Data Collection Instrument.................................................. 38

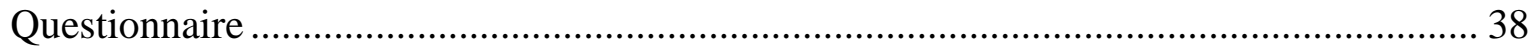

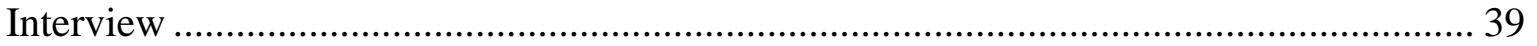

Request of Permission to Conduct the Research................................................................. 41

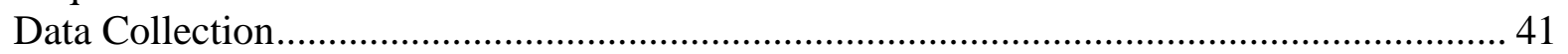


The Motivational Aspect of Using Computers to Write Questionnaire .......................... 41

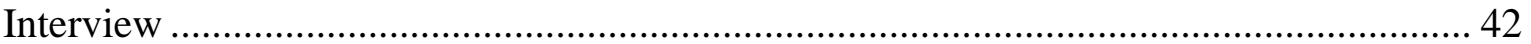

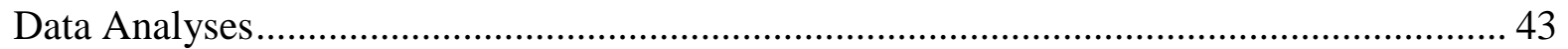

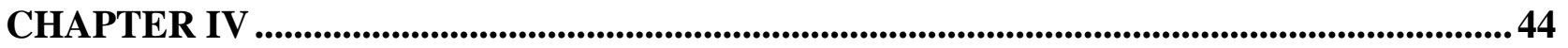

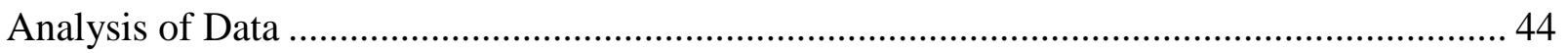

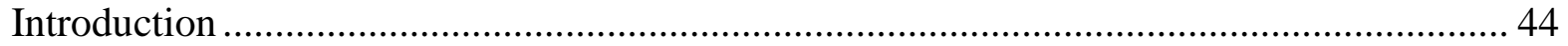

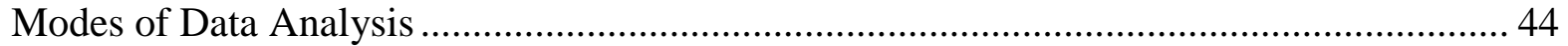

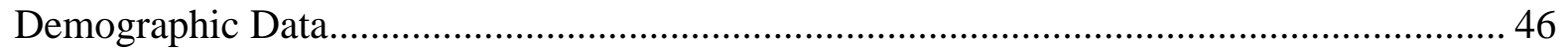

Discussion of Research Question 1 ..................................................................... 47

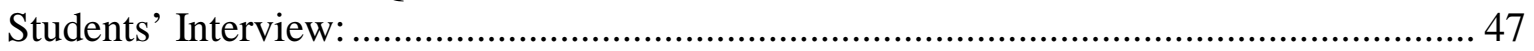

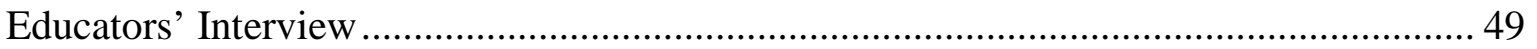

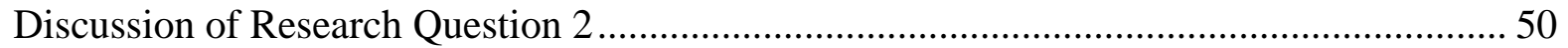

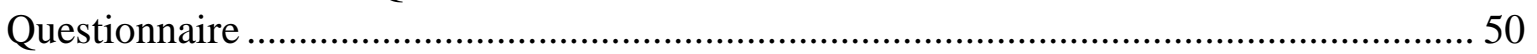

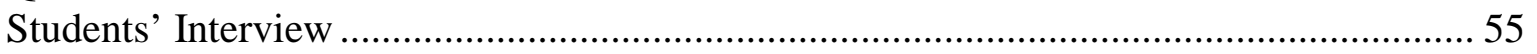

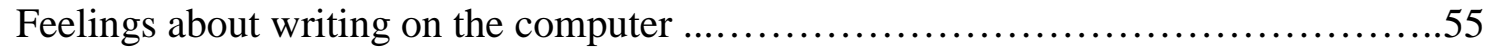

Likes and dislikes about writing on the computers..............................58

Exposure of subjects writing and quantity of writing........................... 60

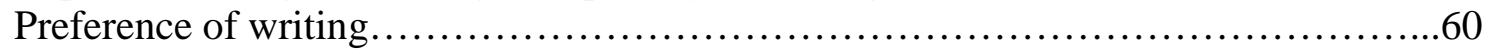

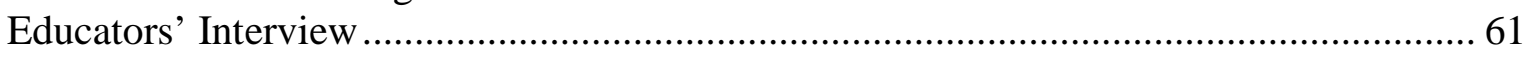

Advantages and disadvantages of writing on the computer.......................62

DreamWriter vs. computer lab ..............................................63

Students' attitude when writing on the computer................................64

ESL and native English speaking students' reaction to writing on the computer........64

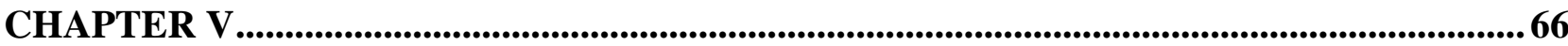

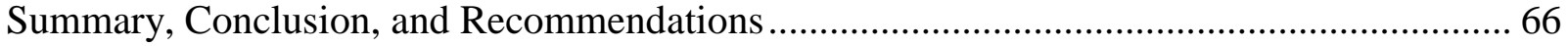

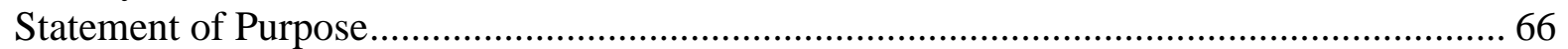

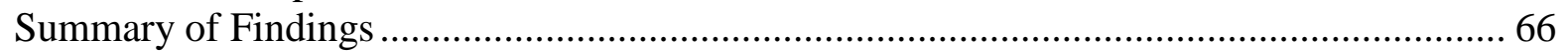

Fourth grade students perception of the importance of computers in the "Student as

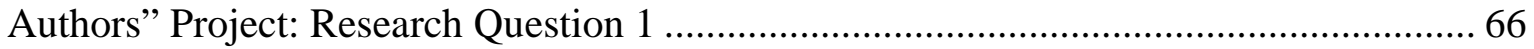

The motivational aspects of using a computer to write in the "Student as Authors" Project,

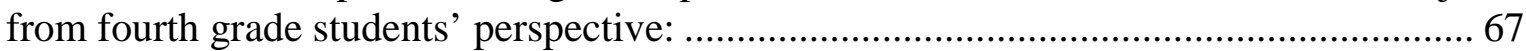

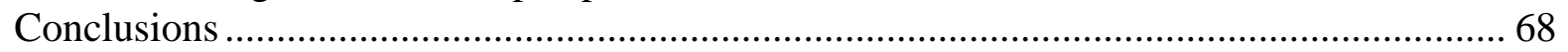

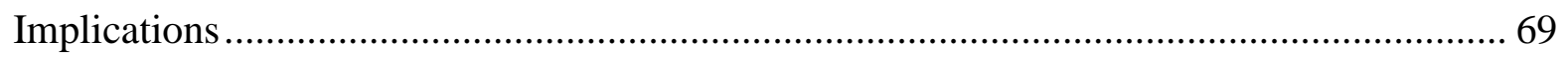

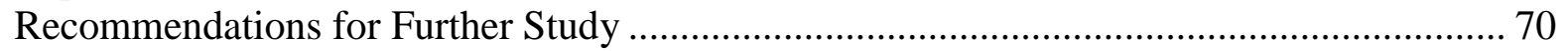

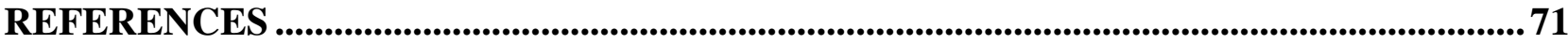

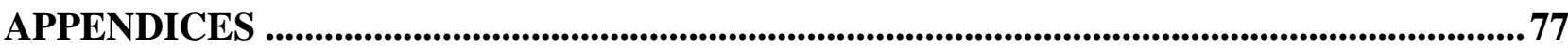

Appendix A: The Motivational Aspect of Using Computers to Write Questionnaire .......... 78

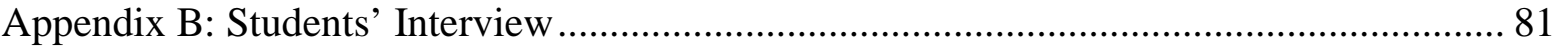

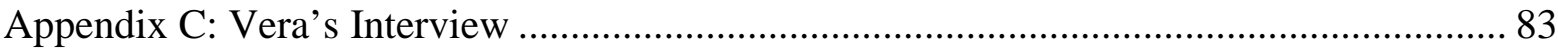

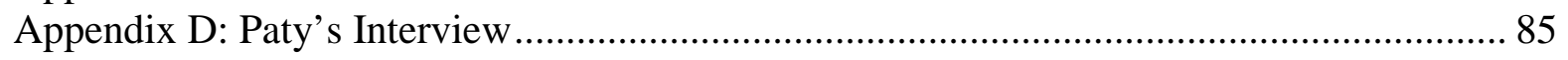




\section{LIST OF TABLES}

Table 1: Results of Questionnaire on the motivational aspect of using computers to write .. 45

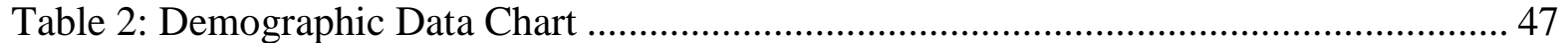

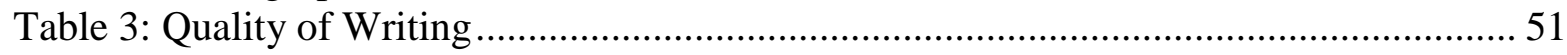

Table 4: Feelings about Writing on the Computer ...................................................... 52

Table 5: Exposure of Subjects' Writing ....................................................................... 53

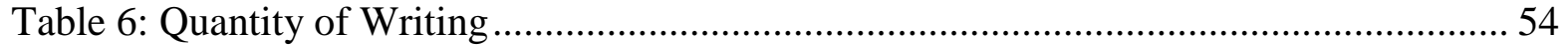

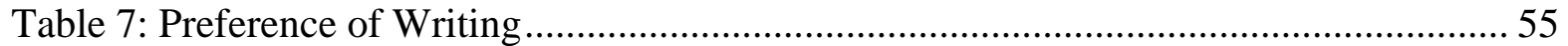




\section{FOURTH GRADE ELEMENTARY STUDENTS' PERCEPTION OF THE MOTIVATIONAL ASPECTS OF USING COMPUTERS TO WRITE IN THE “STUDENT AS AUTHORS" PROJECT}

\section{CHAPTER I}

Introduction

Since the beginning of time technology has been present in the world (Tenner, 1997). But only recently it has been recognized as an essential part of human life. The way we speak, think and act is influenced by technology (US Congress, Office of Technology Assessment, 1995). According to Mitcham (1994), the concept of what technology is and the experts' view about technology has changed throughout the years.

First came the Ancient age, an age where it was believed that nature and God were essential for humanity. Progress and technology were viewed as bad things but still necessary. This was the age of the great philosophers like Socrates when many felt that any object other than the objects of nature were considered technical ones and could lead humans far away from providence and nature, which were the two most important elements of this age.

Then, came the Age of Enlightenment which was first conceptualized in the $17^{\text {th }}$ century but only took place in the $18^{\text {th }}$ with Renaissance. Industries could be found everywhere. Mechanical work, low salary, and long work shifts were part of this age. Advances in military technological findings frightened the world. In this age the creation or discovery of technology was thought to be more important than the purpose for which it was created (Mitcham ,1994). Mitcham (1994) goes further by stating that these two philosophies were then combined into a 
third one called Romanticism. Romanticism is the age in which we now live. Beginning in the end of the $18^{\text {th }}$ century, this age is characterized mostly by duality, in that technology is seen as neither totally bad nor totally good to humankind. It is considered necessary and beneficial to human kind when integrated with human common sense, feeling and affection. Without those elements technology is considered to be evil and harmful to humanity in general. The sense of power that technology gives to people is still subject of concern. The unpredictable outcomes of technology, as well as the problems related to it, make technology one of the most wanted and hated thing in today's society. This duality can be found everywhere from daily activities to complex ones.

Technology is present everywhere and it is part of people's responsibility to cope with it and use it in a proper and beneficial way. Humans play the main role in this age and the appropriate use of technology is still something that people are trying to figure out. To better understand and function in today's world people have to be able to deal with technology. Every system that forms the structure of a society is influenced by the incorporation of technology in it. Major changes have to be made in every segment of society, if development is going to occur, starting with the educational one (Micham 1994; Tenner, 1997).

In order to cope with technological changes, schools have had to adopt and include new technology in their operation and mission to serve students. In today's American schools one can find all sorts of technology, from paper and pencil to photocopy machines and computers.

The U.S government is supporting the introduction of computers and Internet access in schools. They anticipate having this technology in every school by year 2005. "Federal Communication Commission has created $\$ 2.25$ billion annual fund to help schools and libraries pay for Internet connections" (Conte, 1998, p. 29). There is a strong public sentiment that 
education will benefit tremendously from a wired classroom. The Internet and computers are considered to be key tools for promoting citizenship and preparing today's students to face the challenges of a technological society (Chiero, 1997; Conte, 1998).

There are lots of issues concerning the integration of technology in education that have not been explored, especially the issues related to the implementation of computers in elementary schools. To have a great number of computers in the school without incorporating them efficiently in the school curriculum is a waste of time and money. Computers can only work in favor of education if they have experts in education who know how to best apply them in an educational setting (Stronmmen \& Lincoln, 1992).

According to Mergendoller (1997), "analyses of educational technology in American schools indicate that computers are used about 1-3/4 hours per students per week in an average elementary school" (p. 13). Among other things, computers were being used to improve literacy in schools. Research has indicated that classroom computers and the Internet play an important role in the way literacy is taught and learned.

There are controversies concerning this topic, however. Some people believe that computers and the Internet are central tools for teaching and learning; others believe that children should first master the basics of reading and writing in order to be introduced to computers. According to the later view, children can become dependent on the computer and this could cause problems in the child's later life since computers are not always available (Leu \& Kinzer, 1999).

Nonetheless, recent research has indicated that learners who are diverse in terms of ability and ethnicity, and who are diverse in terms of language benefit tremendously from the use of computers since it allows students to work at their own levels and at their own paces 
(Bicknell, 1999; Leu \& Kinzer, 1999). Second language students, for example can have the support of text translation when reading the same text as the rest of the class. This creates a very supportive environment, where learning is a universal language (Leu \& Kinzer, 1999).

Research has indicated that writing is an essential skill that students must master; however, students are neither interested in nor motivated by writing due to its difficulty (Gambrell, Morrow, Neuman \& Pressley, 1999; Silva, 1998). According to Raef (1996), the probable causes for writing being such a hard thing for students are the followings: "lack of modeling of writing, lack of background knowledge, instruction with one emphasis, and lack of motivation" (p. 10).

Bacon (1998) points out that many American institutions face the dilemma of having to decide whether to use computers or traditional instruction methods. Recent research indicates that computer-assisted instruction promotes a student-centered environment which is equivalent or superior to a traditional one (Bacon, 1998; Solomon, 1986). On the other hand, the way that this has been measured over the past years (through standardized tests) is neither clear nor precise in its results when measuring things like technology (US Congress, Office of Technology Assessment, 1995).

\section{Background for this Research}

\section{Using Computers for Writing in Elementary School}

Leu and Kinzer (1999) suggested that writing is an ongoing process, where a real audience and a real purpose are pre-established. Based on this research, over the past decade electronic computer innovations such as the word processor, the Internet and the educational software have been playing an important role in students writing (Leu \& Kinzer, 1999). These innovations have been transforming how writing is being learned and taught. The thoughts and 
theories about writing are being adjusted to fit the needs of the Information Age (Stuhlmann \& Taylor, 1998).

Technology can be used to support a student-centered environment, such as in the use of drill software to promote the "mastery" of basic skills or in the use of word processing, the Internet and problem-solving software that promotes thinking, and collaborative work. It also provides teachers with the opportunity to be facilitators. "Teachers who fall into the later group are among the most enthusiastic technology users because technology is particularly suited to support this kind of instruction" (US Congress, Office of Technology Assessment, 1995, p.2).

Literature shows (MacArthur, 1999; Mott, Sumrall and Hodges, 1997), that writing classes are one of the classes that benefit most from a computer-supported environment. Compared with traditional writing classes, computer-supported ones tend to motivate students to go through each step of the writing process: prewriting, organizing, writing, editing and revising due to the features such as editing tools found in word processors and the attractiveness of some writing software. Thus students write more and in a more independent way than in a traditional class.

\section{The Use of Computers to Write by English as a Second Language (ESL) Students}

According to research conducted by Silva (1998), native and non-native writers have many things in common. Both native and non-native speakers encounter many problems when dealing with writing. Both follow the process of planning, writing and revising, in order to find a better way of expressing themselves. Although the process of writing is similar, the difficulties are greater for second language writers. Their writing product is "more constrained, more difficult to read and less effective" (Silva, 1998, p. 461) to the native speaker's point of view. 
Though they revise their texts more "they lack the intuitive revision (by ear)" (Silva, 1998, p. 461).

According to Edbert and Hansom-Smith (1994), computers serve many positive functions for second language (L2) students. One of the most efficient ways in which computers help L2 writing is in the motivational aspect of the writing process. Leu and Kinzer (1999) state the importance of having a purpose to write. According to these authors, writing has no meaning if the individual who is writing does not see a significant purpose behind it. By providing the L2 learner with a real audience, computers have contributed much to L2 writing. A real audience is interpreted to be those who can read the work on the Internet. "Having their work on the web excites L2 students, motivating them to write in English" (Bicknell, 1999, p. 25).

\section{Motivational Aspects of Using Computers to Write}

Motivation is present in every single task in a learning environment. It is the basic condition for teaching and learning to occur. "Motivated students show interest in activities, feel self efficacious, expend effort to succeed, persist at tasks, and typically use effective tasks and cognitive strategies" (Pintrich \& Schunk, 1996, p. V). Motivation is so important that whenever there is an absence or lack of it the learning is compromised. It is part of the teacher's responsibility to promote a motivated environment (Pintrich \& Schunk, 1996).

Today's teachers are making use of technological tools such as computers to keep students motivated. Recent research (Bacon, 1998; Jankowski, 1998; Owston \&Wideman, 1997) have pointed out the importance of technology in children's motivation. They agree that due to the highly technological world in which children are living, it is mandatory to include technology in the classroom if educators want to prepare children to become educated citizens in today's world (Jankowski, 1998). 
Research comparing paper and pencil versus computer-based assignment has shown that children were more motivated to write when using a computer instead of paper and pencil. They paid more attention to the final product of their writing, and they were more focused on the writing task and they showed greater enthusiasm concerning writing (Owston \& Wideman, 1997).

\section{Current Barriers to Using Computers}

During the past two decades, computers and technology, in general, have been blamed for the good and the bad things that are happening in society. The current approach of having computers in all schools as a means toward and tool for education has been a very controversial issue. Through experience people have learned that computers do not have a life of their own and that for them to be successfully used in schools they must have teachers and students who are open to change and innovations.

Differences between theory and practice when adapting computers as part of the daily routine of a classroom have created numerous barriers (Hoffman, 1997). According to Cooley (1997), "successful implementation of technology is not about equipment, but the empowerment of people" (p. 55). Computer technology can be a useful teaching tool if implemented in a school where the training of staff is consistently provided, the computer is connected to the school's curriculum, technology support is provided and students as well as teachers are engaged and willing to deal with the technology. Most important of all " technology must be seen as a means to an end, rather than an end unto itself" (Mergendoller, 1997, p. 15)

\section{$\underline{\text { Bald Eagle Elementary School }}$}

This research was conducted in Bald Eagle Elementary School, located in northcentral, West Virginia. In the 2000 academic year the school's population was approximately 220 
students, of which about 30 were international ones (approximately 14\% of the school's population). The school has 30 DreamWriters used in their Reading and Writing class.

Computers are being used as means to the achievement of educations equality in a multicultural class through the help of the "Student as Authors" Project. The school's mission statement proposes "empowering all students to achieve that academic potential, to recognize and accommodate individual differences, and to assist students in the development of their sense of self-worth .

The school has the following goals:

- To monitor, enrich, and extend learning opportunities for all children.

- $\quad$ To strengthen the academic program and education experiences for all children

- To develop an organizational structure with in the school that increases collaborations about teaching and learning.

- $\quad$ To assure that all students develop a keen sense of personal and civic responsibility in order to promote student learning.

- To strengthen the school's relationship with parents and learning

The school's major concern is to provide equal and quality education to all students. The recent implementation of the "Student as Authors" Project in the school promotes the incorporation of computers in the writing process.

This research focused on the fourth grade students due to the fact that these students started to use computers as part of their writing in the semester that the study was conducted in 
the Fall 2000 semester, and that approximately $12 \%$ of the grade fourth population was composed of international students, one of the highest percentage of all grade levels. The school's name is a fictitious one to assure the anonymity of the participants in this study.

\section{"Student as Authors" Project}

The "Student as Authors" Project was first implemented in Central Elementary Professional Development School, located in Morgantown, West Virginia, by Anita Nedeff. Through this project the students were able to actually publish their books and get paid for quality work. "The purpose of the project is to enhance self-esteem and acknowledge that children's works have value" (Nedeff, 1996, n.d). The profits made from the selling of the books or donations to the project are converted to the school's publishing company, a non-profit organization that makes this project a reality.

This research was first designed to be conducted in Central Elementary Professional Development school, but due to its closing and to the fact that many of Central's staff and students' population were transferred to Bald Eagle Elementary School, this research also shifted sites.

The "Student as Authors" Project engages students in a meaningful and rewarding writing experience. Technology components as computers, video cameras, and audio are used in order to motivate students to write, as well as to promote collaborative work and sharing of ideas and experiences.

\section{$\underline{\text { Problem Statement }}$}

The problem statement of this research is was to describe fourth grade elementary students' perception of the motivational aspects of using computers to write in the "Student as Authors" Project. 


\section{Purpose of this study}

Smith (1997) points out that "between 1979 and 1989, the percentage of children aged 510 in the U.S who spoke a non-English language at home and had difficulty speaking English increased from 3\% to 5\% where it remained from 1989 to 1995" (p.10). The author also found out that the dropout rate of ESL students from 16 to 24 years old (44\%) was much higher than the students who spoke English as a first language (12\%). Today's American elementary schools face the challenge of offering ESL students the same opportunities in education that Englishspeaking students would have (Leu \& Kinzer, 1999).

English as a Second Language research has noted that one of the most difficult and consequently one of the last skills to be acquired by ESL students is the writing skill (Kroll, 1990). The "Student as Authors" Project was developed by Anita Nedeff with the help of Central Elementary school's staff, aiming to diminish the social cultural gap found by ESL elementary school students.

By valuing their culture and treating each student as an individual with talents and limitations, the "Student as Authors" Project has contributed to the enhancement of writing and reading skills of elementary school students (Barksdale-Ladd \& Nedeff, 1997). By identifying the students perspective of the importance of the computer to the project and the motivational aspects of using a computer to write in the "Student as Authors" Project may determine the better use of technology in the project.

By choosing Bald Elementary School's fourth grade students to be part of this research the following facts were taken into consideration: the percentage of international students in the fourth grade classroom (12\%), and the fact that for a great number of students it was the first 
year that they were introduced to the "Student as Authors" Project and to a much greater use of computers in their writing learning process.

This research intended to identify the motivational aspects of using the computers to write in the "Student as Authors" Project and to identify the perception of the importance of the computer in the Project by fourth grade students participating in the "Student as Authors"

Project. It was also the intend of this research that its results could be used to the enhancement of the use of computers in the "Student as Authors" Project.

\section{$\underline{\text { Research Questions }}$}

This research answered the following questions:

a) How do fourth grade students perceive the importance of the computer in the "Student as Authors" Project?

b) What are the motivational aspects of using a computer to write from the fourth grade students' perspective?

\section{$\underline{\text { Assumptions }}$}

The following assumptions were made in this study:

1. All participants had computer-enabling skills appropriate for $4^{\text {th }}$ graders in the U.S.A.

\section{Limitations of this Research}

The study was limited in the following ways:

1. The number of students was limited to 12 , which included 2 international students. A small sample size was used successfully for this study.

2. Other variables such as getting paid to write and gender were not taking into consideration in this research. 
3. The novelty aspect of using a computer as part of the writing process in the "Student as Authors" Project could not be measured or addressed in this study.

\section{Definition of Terminology}

EFL: English as a Foreign Language. "English language learned in a non-Englishspeaking environment" (http://www.glc.k12.ga.us/qstd-int/ancill/esol/gl-esol.htm).

ESL: English as a Second Language. For the purposes of this study, English as a Second Language students are those whose primary language(s), or language(s) of the home, is/are other than English, and who may therefore require additional services in order to develop their individual potential within American schools (http://www.bced.gov.bc.ca/esl/policy/definition.htm).

L1: First Language. In this study, L1 describes the English language.

L2: Second language. In this study, L2 describes the language spoken in China and Switzerland.

Motivation: "motivation is the process whereby goal-directed activity is instigated and sustained. It is a process rather than a product. As a process, we do not observe motivation directly but rather we infer it from such behaviors such as choice of tasks, effort, persistence, and verbalizations" (Pintrich and Schunk, 1996, pg. V).

DreamWriter: "The DreamWriter is a mobile laptop-sized computers and a Rol-A-Lab electronic cart (to store, recharge, and transport the computers from class to class). It has Word processing software, Typing $\mathrm{Cool}^{\mathrm{TM}}$ keyboarding software, calculator and world clock, expandable memory with PCMCIA card, student and teacher password, capacity for 128 uniquely named files, Macintosh and Windows file transfer, and optional infrared port for wireless printing and file transfer" (http://www.dreamwriter.com). 
LEP: Limited English Proficient. For the purpose of this study LEP was used to address students whose language spoken at home were different from English and who had difficulties to master the language. 


\section{CHAPTER II}

\section{Literature Review}

There are many ways to think about writing. According to Solomon (1986) writing is a thinking process where communication is seen as the ultimate goal. Leu and Kinzer (1999) go further by emphasizing the importance of writing for a real purpose and establishing a correlation between reading and writing. Writing, in these authors' points of view, can also be considered a complex translation process where thoughts take the form of words. Unlike the speaking process where this translation is done almost immediately, the writing process is done slowly and continuously.

Solomon (1986) states that writing is considered one of the best ways of learning a language. One of the reasons is that when a person writes, he/she has to use almost all of the skills that make a person communicatively competent in a language. The person has to listen to his/her thoughts, translate it into words, and read the words that he/she has written, edit them, and publish his/her work in order to have his/her voice heard.

The writing process is divided into the following parts: prewriting, drafting, revising, editing, and publishing. Those parts do not necessarily have to be followed in a particular order (Leu \& Kinzer, 1999; Solomon, 1986).

Literacy is the main focus of education systems all over the world. Though writing and reading are considered to be the basic skills that a child needs to develop in school, this is not always easy to accomplish. To get children interested and motivated to write is a difficult task that teachers have to handle in their classrooms (Jankowski, 1998; Leu \& Kinzer, 1999; Solomon, 1986). 
This research investigated fourth grade elementary school students' motivation towards writing when using computers. This research aims to contribute to elementary school teachers' and students' teaching and learning experiences.

In order to better understand the elements that form this research, this review of literature was divided into the following parts: using computers to write in elementary school; using computers to write by ESL students; motivating aspects of using a computer to write; identifying current barriers of using a computer to write; and the "Student as Authors" Project.

\section{Using Computers to Write in Elementary School}

Today's teachers consider writing as a process (Gambrell et. al, 1999; Leu \& Kinzer, 1999; Solomon, 1986). But to engage students in this process is complicated. Some teachers struggle to get students to put their thoughts on paper (Jankowski, 1998). One of the main reasons for this is that the process of revising and editing are time consuming and take a lot of work. When children decide to write they know that they will have to revise their work and go through a process of erasing, changing, and modifying that are considered boring and frustrating (Solomon, 1986). With the introduction of computers in schools, children's attitudes concerning some of the procedures in the writing process has changed considerably (Gambrell et al., 1999; Leu \& Kinzer, 1999; MarcArthur, 1999; Solomon, 1986).

Word processors help children to focus more on the content of what they were writing instead of the mechanics involved in the writing process. Students feel more free to write due to the helpful features that the word processor offers. The revising and editing processes are no longer considered to be the monsters of the writing process. Students can change their writing as many times as they want without having to manually rewrite the text. Editing and revising 
became simple processes whereas creativity became an elaborated one (MacArthur, 1999;

Nichols, 1996; Owston \& Wideman, 1997; Solomon, 1986)

This fact can be observed in a research done by Nichols (1996) when comparing compositions written using pencil and paper with those written using the word processor. It was found that the quality of the composition, accuracy of grammar, and reading ease had no significant difference between the two approaches. However, the number of words and length of the composition of students that used the word processor to write was significantly greater and longer than those who used paper and pencil.

Among the various activities that can be done using a computer, word processing is still one of the most used technological tool in the educational field. It not only makes the writing process easier but also motivates collaborative work. The legibility and neatness of work that is displayed on a computer screen is much higher than on paper due to the easy editing process, in addition it also provides more information at a time due to the screen's feature, motivating students to do peer editing and engage in a collaborative environment where each piece is valued and shared (Merrill, Hammons, Vincent, Reynolds, Christensen \& Tolman, 1996; Nichols, 1996; Owston \& Wideman, 1997; Solomon, 1986).

Many authors such as Labbo, Reinking and McKenna (1999) and Owston and Wideman (1997), advocate the use of computers to write at an early age. According to them, children can identify the letters on the keyboard easily and are not constrained by the lack of coordination required to write with paper and pencil. The use of concept keyboards allows children from an early age to be introduced to the use of computers to help their literacy process. A concept keyboard is a "board divided into pressure points, which when pressed responds like the keys on the main computer keyboard" (Broomfield \& Combley, 1997, p. 41). 
Pictures related to the sound of the letter form the keyboard overlays which facilitate young learners to figure out which letter to use in the writing process. These overlays can also include rimes and whole words creating groups of sound-related words that can be easily identified by the learner (Broomfield \& Combley, 1997). However, the software available in the market that can be used with the concept keyboard is limited.

According to Jankowski (1998), computers and peer tutors can contribute to students writing development making it sometimes possible for students to master writing without totally mastering spelling and handwriting.

On the other hand, Oppenheimer (1997) argues that very young children, preschool through third grade, need to be evolved in activities that help them to develop their social skills and experience the five senses before being introduced to any technology. They need to be given opportunities to feel, hear, smell, see and taste what the world has to offer them and hands-on activities have proven to be more efficient than any technological support. Humans learn by interacting and by experiencing the real world.

Opinions concerning the use of computers diverge "because research on the brain is still so sketchy, and computers are so new, that the effect of computers on the brain remains a great mystery" (Oppenheimer, 1998, p. 53).

According to Leu and Kinzer (1999) word processing software can be of great help to teachers and students if it is used in a way that would add to and not replace formal instruction or traditional components. Besides word-processing software, computers can offer many other facilities to writing teachers. The Internet and educational software have been making a great impact on the teaching of the language arts (Gambrell et. al, 1999; Leu \& Kinzer, 1999). 
Among the reasons why writing teachers are celebrating the introduction of computers and network connections in schools are the easy process of sharing documents and texts which motivate the establishment of a collaborative environment and the use of electronic mail and bulletin boards for asynchronous communication (not in a real time) between members of a writing class or a larger community, as well as real time or synchronous communication between these groups (Hawisher \& Leblanc, 1992).

Constructivism has best-supported group and pair work. According to its principles when children work together socializing and interacting with other children in a positive environment, they can have the unique experience of constructing, building up concepts by sharing their experiences and knowledge. With the introduction of technology in schools, collaborative work has become more popular, especially collaborative writing. In a collaborative writing setting children learn to express their ideas, question and accept other's ideas, understand different cultures and view their colleagues as resources and not as competitors (Bacon, 1998; Strommen \& Lincoln, 1992).

Children that are more acquainted with computers, work with those who do not master the computer's features very well (paired keyboarding), making the children who better master computer skills to feel important and as a consequence these children feel more motivated to learn. According to Gambrell et. al student's “computer ability seems to enhance his social standing with several of his peers" (p. 312, 1999). According to Gambrell et. al students tend to look for the students with computer ability to work with in assignments where computers are not involved. Other effective collaboration computer based activities are: electronic pen pals, electronic field trips, Internet workshops, Internet inquiry, sending e-mails to experts, publishing 
students' work on the Internet, electronic portfolio and electronic conferences. (Gambrell et. al, 1999; Leu \& Kinzer, 1999)

What makes these computer-based activities on the Net so special is that children get engaged in writing and researching because they know that their writing can be read by a real audience (Bicknell, 1999; Leu \& Kinzer, 1999). When writing is meaningful and servers as an authentic communicative purpose it makes students more aware of the language, thereby increasing their desire to be understood and their willingness to write properly in order to share and express their thoughts. As a result, children become more conscious and critical about writing as well as reading, thus developing their critical thinking (Leu \& Kinzer, 1999; Stuhlmann \& Taylor, 1998).

The possibility of including graphics, video, sounds and animation in their publication, as well as hypertexts (links to other documents), makes virtual publishing one of the most complete tools to enable children to expand their creativity and imagination (Schrum, \& Berenfeld, 1997).

According to Gambrell et al. (1999), computers, especially the Internet, facilitates the integration of reading and writing: "the skills required for writing with technology prepare students to be better learners in school and for the world beyond school" (p. 165).

\section{The Use of Computers to Write by English as a Second Language (ESL) Students}

The increasing number of ESL students in the U.S. elementary classrooms is making many teachers wonder about the best practices in teaching ESL students. According to Fitzgerald (1994), "providing a safe environment, and offering lots of practice in authentic situations, would seem highly likely to help ESL learners" (p. 354). Computers have been recognized as one of the most efficient tools in promoting a friendly environment and in giving ESL students the opportunity of working at their own pace, integrating sound, graphics, texts and animations in a 
single device plus providing the opportunity of having students writing for an authentic purpose and for an authentic audience (Fitzgerald, 1994; Kang \& Dennis, 1995).

Second language and native language processes of writing are very similar. They both go through the steps of prewriting, writing, revising, editing and publishing without a particular order (Gambrell et al. 1999; Leu \& Kinzer, 1994; Pennington, 1989). However, research shows (Silva, 1998) that L2 writer's texts are "less fluent (fewer words), less accurate (more errors), and less effective (lower holistic sores)" (p. 668). L2 students have to be closely guided in order to better succeed on a writing task. According to Merill et al. (1996), "learning a new language is supported by meaningful input, social interaction, risk taking, and purpose” (p.332). Technology comes to provide the right environment to help the learning of a language by facilitating interaction, encouraging students to take risks and giving them purpose to communicate through tools such as the Internet, word processor and educational software.

Not only word processing but also multimedia educational software expose ESL students to different learning options. The possibility of creation that is made possible by the advances of technology is endless. ESL students can read books in their own language as well as in English; they can record their voice, and listen to the book story as many times as they want; they can focus on an specific area skill, such as grammar; and they can enjoy their learning by interacting in many different ways when using the Internet. All of these advances in technology allow ESL students to learn at their own pace having authentic material as part of their learning (Merill et al., 1996; Kang \& Dennis,1995). "Second language students can derive many of the same benefits from computer-assisted composition as a native language writer, and possibly more" (Pennington, 1989, p.81). 
Nonetheless, Oppenheimer (1997), noted that any kind of technology is useless and does not enhance learning if it is taken apart from the instruction as a whole. Computers are only tools that can be used in order to supply writing instructions with alternative material in the teaching of writing. Integration is the key word for enhancement of instruction, and as a consequence of learning when using technology.

According to Edbert and Hansom-Smith (1999), with the advances in technology communication and with the implementation of the Internet in schools, ESL students have now the chance of getting involved in an environment less threatening than the real class context. The same authors state that with the Internet and network communications students feel more encouraged to engage in collaborative writing. Students can exchange ideas and co-author each other work. Moreover, this environment makes possible a certain environment where students feel safer to express their ideas and share their experiences (Edbert \& Hansom-Smith, 1999). On the other hand, to use the computer to foster real communication through writing can be challenging in many ways. The sense of anonymity in a computer-mediated interaction can lead some students to use inappropriate and offensive language in his/her communication. Another challenge is the velocity of the synchronous (real time) communication that can result in chuck sentences and in a low value of the written structure. The discussion in this kind of virtual environment has to be closely monitored and guided to be considered valid in the education field (Edbert \& Hansom-Smith, 1999).

Reading authentic materials from the Internet and writing to an audience with a purpose makes the experience of writing meaningful. ESL Students tend to take advantage of those moments in a very particular way. They become more careful about their writing and they start to look at their work as a whole instead of as a set of grammatical rules all together (Leu \& 
Kinzer, 1999). Moreover, the chance of interacting with teachers and colleagues when writing, promoted by the advantages of writing using the computer -- the screen shape, the neatness of the text and the easy editing features -- make this kind of environment ideal for developing speaking skills, such as negotiation of meaning, correlation of thoughts, and support of ideas (Gambrell et. al, 1999; Leu \& Kinzer, 1999). When students use their knowledge of computers to teach their peers they are developing their social skills, advancing in their computer knowledge and developing their speaking as well as their self-esteem. Most of the times ESL students do not feel comfortable in asking their teachers for help but they feel comfortable in asking a classmate. In this environment where students can interact without much fear, students fell motivated to use language in a natural way. Through this kind of knowledge sharing a proficient student in English can have somebody with limited English knowledge to help him/her with computer features and vice versa, creating in this way an environment where cooperation and respect are always present (Edbert \& Hansom-Smith, 1999; Leu \& Kinzer, 1999).

Computer Assisted Language Learning Labs can help teachers by providing an environment where individual needs are more easily addressed. Computers are not to be seen as solutions to the teaching of ESL students, but hold promise as useful tool when managed by an experienced instructor (Edbert \& Smith, 1999). For this to happen, instructors have to first consider their class' needs and goals, then consider

Whether the media elements $\sim$ aural, visual and textual can be used in ways that make sense; whether the kind of manipulation and control of material is complementary to and translatable to existing classroom contexts; what adjustments might be necessary in the existing classroom context; and whether the technology is valuable pedagogically (Edbert \& Hanson-Smith, 1999, p. 467). 
According to Pennington (1989), although most ESL students report that they enjoy using computers to write and that it makes the writing process easier, some do not share the same opinion. There are some ESL students who do not feel comfortable with technology and that struggle in using it. Therefore, their experience when writing using the computers are limited to worries concerning the mastering of technology instead of the mastering of the writing process. For those students traditional class instruction would be of greater efficiency than the technological environment. It is the teachers' duty to identify these preferences by observing students' behavior and giving a computer attitude survey before the beginning of activities on the computers or just by asking students and addressing their fears and concerns and making sure to provide each student with the proper tool that will most help in their learning. Students should be introduced to technology, as they need it, in order to complement instruction. Teachers have to serve as models in the introduction of technology to students. It is also their responsibility to choose the appropriate educational software or computer activity that better suits ESL students' level of English proficiency (Gambrell et al., 1999; Merrill et al., 1996; Pennington, 1989). “The integration of the computer into second language composition can be an important factor in the growth of students as language users and writers" (Pennington, 1986, p. 96).

\section{Motivational Aspects of Using Computers to Write}

Every human action involves motivation. The sustaining of an action is only accomplished if motivation is involved. "Motivation can affect both new learning and the performance of previously learned skills, strategies, and behaviors, which has important implications for schooling" (Pintrich \& Schunk, 1996, p.5).

The consciousness of successful achievement of learning goals promotes an increase in motivation that makes students willing to engage in more challenging learning experiences 
bringing up new goals to their leaning process. The designing of an activity and the freedom of choosing them play an important role in students' motivation. Students show interest and are motivated by activities that they believe to be of importance to increase their learning (Liu \& Johnson, 1998; Pintrich \& Schunk, 1996). "When students have a choice, what they choose to do indicates that they are motivated to work on" (Pintrich \& Schunk, 1996, p.14)

Learning and motivation are closely connected. Although one can learn without being necessarily highly motivated, one only shows the learned skills once the motivation feature is highly present (Liu \& Johnson, 1998; Pintrich \& Schunk, 1999). There are two common types of motivation in the learning process: intrinsic and extrinsic motivation. "Intrinsic motivation is motivation to engage in an activity for its own sake; extrinsic motivation is motivation to engage in an activity as a means to an end" (Pintrich \& Schunk, 1996, p.284). Intrinsic motivation is believed to play a more relevant role in students learning achievements. "Students intrinsic motivation can be affected by four sources: challenge, curiosity, control, and fantasy" (Pintrich $\&$ Schunk, 1996, p.285). In order to keep intrinsic motivation alive, teachers have to be able to provide learning situations where those four components are present. Moreover, they have to engage children in challenging but not extremely difficult activities, to promote an environment where children pursue their learning and not grades, and to develop students self evaluation and independence a hard but not impossible task to accomplish (Pintrich \& Schunk, 1996). The authors explains that extrinsic motivation, on the other hand, relates to factors outside the student such as external reward or punishment for taking an action, taking examinations and peer/social pressure. The balance between extrinsic and intrinsic motivation play an important part in the students learning process. 
Technology can be seen as a tool to help teachers accomplish the task of keeping student motivated to learn. Children's attitudes toward the use of computers is, with some exception, positive. Some of the features found in computers resemble those of daily technology features such as TV. Familiarity with those technologies enables children to feel comfortable and not threatened by computer media (Liu \& Johnson, 1998).

Research has shown that computers can enhance motivation in the writing process (Gambrell et al., 1999; Kang \& Dennis, 1995; Leu \& Kinzer, 1999). The main reason for this to happen is the advances in technology, making word processors, the Internet and educational software meaningful tools that help the writing process. With word processing, editing became easier which motivates children to write more. The neatness of the display of the text on the computer screen motivates children to share their work with others. The Internet made publishing a reality. Today's children can share their writing with their school and home community as well as the world. E-mails and on-line dialogs brought back the use of writing in communication. Students are highly motivated when they know that their writing is going to be read by a person other than their teacher (Gambrell et al., 1999; Kang \& Dennis, 1995; Leu \& Kinzer, 1999; Schrum \& Berenfeld, 1997).

In a computer-based environment teachers can monitor students' motivation by selecting appropriate activities to suit individual needs, avoiding a high level of students' anxiety in accomplishing the tasks, promoting a safe environment to help students with special needs, such as ESL students, to engage in learning more easily. In a computer-based environment teachers can observe better what activities interest students. Teachers can also identify students' weakness and strengths by assigning activities for each level of difficulty. The students in this kind of 
approach have a more individualized and meaningful class that address their individual needs (Fitzgerald, 1994).

"Issues of motivation are closely tied to feelings" (Leu \& Kinzer, 1999, p. 255).

Therefore, computers can only be seen as a tool in order to set up a proper learning environment. It depends on the instructor to promote, with the help of the computer, learning experiences that are in different ways challenging, enjoyable and meaningful to the students (Egbert \& HansonSmith, 1999; Gambrell et al., 1999; Leu \& Kinzer, 1999;).

\section{Current Barriers}

The common conclusion drawn by the correlation between technology and children is that together they form a perfect match. However, this is not always true. Children as individuals differ in their attitudes concerning technology. Learning styles dictate children's behavior in accepting or denying technology as a learning tool. Teachers have to be aware of those differences when choosing technology to be part of his/her instruction (Knapp \& Glenn, 1996).

It is also important to recognize that effective technology use is better characterized in a student-centered approach instead of a teacher-centered one. Thus, in order to incorporate technology in the classroom, teacher and students have to be willing to experience a studentcentered environment. Generally students used to be treated as an empty box that teachers load with information which they think is important to students' lives or with information that has been pre-established by the school's curriculum. Students are used to playing a minimum role in their own learning process. With the introduction and advances of technology in education, this kind of practice is not efficient and it causes confusion and frustration for many students. It is part of the teachers' responsibility to guide students to be independent learners. It is their duty to teach them how to look for information independently; how to engage in collaborative work; 
how to judge criticize and choose relevant information; and how to evaluate and measure their own group. With technology and advances in learning theories, students are asked to be more responsible for their own learning (Knapp \& Glenn, 1996).

On the other hand, there are those students who cannot cope with technology and who can develop computer anxiety as well as communicative anxiety (Hawisher \& Leblanc, 1992; Rose, 1989). According to Rose (1989), computer anxiety is the fear or uneasy state that a person feels when facing the possibility of using a computer or even watching others using it. Communicative anxiety can be identified in synchronous -- real time -- communication or asynchronous-not in real time- communication. According to Hawisher and Leblanc (1992), in these types of communication a person takes many risks. Among those are the risks of being misunderstood, and/or of being ignored. The anxiety promoted by the need for acceptance, of others' responses is extremely harmful to the learning process and can lead to a fear of interaction in any educational settings.

Besides pedagogical issue concerning technology, there are physical, structural and administrative barriers that cannot be overlooked. After the introduction of computers in schools, school administrators have found out that dumping computers into schools and having sporadic training workshops for teachers are not enough in order to see the results of technology reflected in the education practices (Hoffman, 1997; Oppenhelmer, 1997).

Currently, the majority of the technology budget is spent in its majority in hardware and software. The schools do not spend more then $15 \%$ of its technology budget in the training of staff. With technology, teachers are required to do more and receive the same things that they would be receiving when not using technology in class (Marcinkiewicz, 1994). 
Knapp and Glenn (1996) point out that teachers have their own beliefs about teaching and to have them adapt those beliefs in order to incorporate technology in their classroom is most of the time a hard thing to accomplish. The sudden change of roles and the question about the efficiency of technology to the learning process frustrate a great number of teachers who, without strong support by schools' administrators, have high chances of giving up on technology.

We are in a high technological environment where critical thinking and creativity are much more important than the learning of separate skills. To have students to think critically with technology's help is the teachers' ultimate goal. In order for this to happen the training of staff in today's world cannot be limited to the teaching of basic computer skills. It must provide teachers with enough background to be able to best integrate technology into the curriculum. Universities should better prepare the upcoming educational professional in the understanding of the application of technology into the curriculum (Crook, 1994; Hoffman, 1997; US Congress, Office of Technology Assessment, 1995).

Appropriate training of staff and administrative support are only two of the many barriers that schools face when integrating technology in education. Among these are equal access, computer maintenance, technology coordination, and community and school participation (Crook, 1994; Hoffman, 1997).

Equal access to technology is today's biggest issue in education. Schools do not have the appropriate number of computers to efficiently address students' needs. In some schools the computers that are available do not have a proper configuration to handle the advances on the educational software industry. Moreover, the lack of computer maintenance and technical 
support discourage the use of technology in the classroom (Crook, 1994; Hoffman, 1997;

Oppenheimer, 1997).

Computers, as any other machines, are likely to show problems that teachers do not know how to solve; thus making technical support indispensable in the encouragement and success of teachers' use of technology. It is recommended that schools hire a technology education major to serve as a coordinator for the technology program, giving educational support to teachers in how to integrate technology into the curriculum, as well as technical support for solving problems related to hardware (Crook, 1994; Hoffman, 1997).

In addition, it is also recommended to get parents and community involved in the decision concerning the use of technology. For instance, parents, community, administrators, and teachers can together make important decisions such as policies concerning using the Internet; how to deal with copy righting issues; privacy of students' records; and control of student access to objectionable material (Hoffman, 1997; US Congress, Office of Technology Assessment, 1995).

When teachers discover ways in which technology can strengthen their teaching, helping them carry out administrative tasks, and enriching their professional growth, technology starts to be seen as a useful educational tool. Moreover, when teachers stop thinking that technology is the solution for all the educational problems and start to work with technology in order to help address some of these problems, the enhancement of educational strategies occurs (Hoffman, 1997; Leu \& Kinzer, 1999; Oppenhelmer, 1997).

\section{"Student as Authors" Project}

The "Student as Authors" Project was first developed in 1991 by Anita Nedeff and faculty members of Central Elementary Professional Development School. This school was 
located in Morgantown, West Virginia, and presented a unique setting by having almost one third of its population formed by international students (Barksdale-Ladd \& Nedeff, 1997). This school had as its main goal the improvement of students' self-esteem. According to Nedeff (1997) Central's teachers were worried about students writing, reading and critical thinking skills. By accessing the students' level of self-esteem through a survey developed with the help of West Virginia University's Psychology Department and by observing the need of students' improvement in this area and in the language arts the school's faculty decided to support the "Student as Authors" Project. Actually as stated by Nedeff (personal communication, 2000) the "Student as Authors" Project was idealized in an attempt of Nedeff to minimize the barriers of ESL students in the learning of a new language, by having them introduced to literature in a pleasant and worthwhile way. The project was so successful with those students that the idea was then accepted by other members of the school making it a school project in which Anita Nedeff was the Project's coordinator and the person responsible to carry on the Project.

The "Student as Authors" Project is a unique project. "Books of all genres are written by children, for children throughout the country in English and 12 other languages, including Signed English" (Nedeff, 1997, p.19). The children are the ones that run and support the project, contributing to its organization and self-maintenance. In 1991, students at Central Elementary Professional Development School were given the responsibility of finding out the most costeffective way of publishing a book. After a lot of research, students came up with what is the material used to produce the books until today (Barksdale-Ladd \& Nedeff, 1997).

A contest was held to determine the name of Central's Elementary publishing company. An international student won the contest and Central's PDS Publishing Company was named 
WORM Publishing Company, " being and acronym for the Worlds of a Reader's Mind" (Barksdale-Ladd \& Nedeff, 1997, p. 567).

In this project children receive money for good work. "An agreement is signed by authors and parents giving WORM Publishing Company the rights to the original copies of the studentauthored texts. Following that agreement, the authors are provided a one-time only payment and presented copies of their published products" (Nedeff, 1997, p. 19). The payment of students' work was justified by the inconsiderable profit that they would make, each student could not earn more than $\$ 3.50$ a year according to rules established by the students. In addition, students, like actual writers, were writing quality books to be published and they went through the same process that a writer did therefore they deserved to receive the same kind of reward. This made the students' experience even more significant and real.

In 1992, the project had established a school store run by the students. In this store students sold their own writing and creative work. The profits of any activity related to the project returned to the project. The "Student as Authors" Project "is a non-profit organization sponsored by business and patrons throughout the United States" (Nedeff, 1997, p.20).

During the project students are introduced to different kinds of literature as a warm-up to the writing process. In the "Student as Authors" Project. The students are supposed to write drafts of their work, share it with their classmates, analyze the suggestions made to their work, have it revised by a peer editor, make the corrections necessary and have a teacher-author conference where other suggestions and corrections could be made. At the end of the process the students would have written at least four drafts of a work until it is considered a final product. At the beginning of the "Student as Authors" Project the students did not have access to computers. According to Nedeff (personal communication, 2000), the students did not have any problem in 
writing the drafts and sharing with their classmates, but they were not so enthusiastic about the reviewing and editing stage.

About five years after the "Student as Authors" Project was launched Central Elementary Professional Development School received twenty-two computers from West Virginia University. The school's ESL educator, Anita Nedeff, soon noticed the changes in students' writing. Nedeff (personal communication, 2000) reports that she noticed that students wrote longer drafts and that they were not afraid of making changes to their work, due to the easy way of editing their work on the computer. In order to give students equal opportunity to use the computer for writing the students were divided into two groups, one would go to the computers, which were in different places in the school, while the other group would stay in the classroom for half of the Writing and Reading class time, then they would change roles (Nedeff, personal communication, 2000).

Central Elementary Professional Development School was closed in 1998. Part of Central Elementary Professional Development School staff and students were transferred to Bald Eagle Elementary School. Among the professionals that went to Bald Eagle Elementary School was Anita Nedeff and among the students there were a great number of Central Elementary Professional Development School's international students (Nedeff, personal communication, 2000).

From the 22 computers lent by West Virginia University Anita Nedeff was allowed to take nine to Bald Eagle Elementary School. It was a surprise for Anita Nedeff to find out that the school had a computer lab and 30 DreamWriters. The DreamWriters are placed on the aisle near Anita Nedeff's room. They are always charged and students have free access to them. A 
DreamWriter is assigned for each student. Students from different grades share the same Dream Writer and can work in different activities related to writing at different time.

According to Nedeff (personal communication, 2000) the implementation of the "Student as Authors" Project at Bald Eagle Elementary School was smoother than at Central Elementary Professional Development School. She pointed out that the experience acquired through the work at Central Elementary Professional Development School helped to speed up the implementation process. She could prevent many of the problems that could have resulted from this process. Bald Eagle Elementary School publishing company was named AIR Publishing, which stands for All Intelligent Readers, the more you read and write the more you know. The name was chosen through a school contest that involved the fifth grade students in creating a name and choosing four from the ones that they had created after there was a school contest to choose among the four. The local business and members of the community that supported the program at Central Elementary Professional Development School by donating $\$ 100$ for each class continued to do the same at Bald Eagle Elementary School. The project is still supported by the sale of its own products and by business donation. All sales and money donated are applied to the maintenance of the project assuring the self-supportive aspect of it (Nedeff, personal communication, 2000).

The project by its entire means has been considered a great success in the educational field and an important contribution to the teaching and learning of the language of arts. 


\section{CHAPTER III}

\section{Methods and Procedures \\ Overview of this Chapter}

The purpose of this study is to describe the motivation aspect to write when using computers by fourth grade students participating in the "Student as Authors" Project at Woodburn Elementary Professional Development School.

The following methods and procedures were chosen to achieve the purpose established above: 1) identification of the problem, 2) review of literature, 3) identification of participants, 4) settings, 5) identification and creation of data collection instruments, 6) request of permission to conduct the research, 7) data collection and 8) data analyses.

\section{$\underline{\text { Identification of the Problem }}$}

According to Arnore and Ruth (1999), motivation is the means by which one can explain the reason for a behavior. The chances of a child to engage in an activity more than once without being obliged are quite unlike if they are not motivated to do so. Extrinsic as well as intrinsic motivation play important roles in the learning process.

In educational settings, writing was considered a very complex and tedious assignment due to the repetitive process of writing everything by hand after a revision of a draft. Computers have been claimed to contribute to a great extent to motivate students to write by creating a less tedious and repetitive environment while facilitating the process of edition and revision (Owston \& Wideman, 1997; Raef, 1996; Solomon, 1986).

Although many studies have been done addressing the issue of motivation when writing with a computer (Hawisher \& Lebanc, 1992; Jankowski, 1998; Kahn, 1999; Owston \& 
Wideman, 1997; Raef, 1996; Solomon, 1986), to the researcher knowledge, none has been done in this area focusing on a multicultural elementary school environment.

Thus, by observing students' reactions when writing on the computers and conducting an in depth review of literature in this area, the researcher thought it would be of great value for multicultural elementary schools to have a better understanding of ESL and native English speaking motivational aspects in using computers to write by analyzing it in the "Student as Authors" Project. A project that has already demonstrated its effectiveness at Central Elementary Professional Development School and now it is helping the children at Woodburn Elementary Professional Development School to achieve the supreme goal of a writing program that is to have students seen writing as an enjoyable and pleasant activity, a way to enjoy themselves and have fun.

\section{$\underline{\text { Review of Literature }}$}

An in-depth study of literature related to the motivational aspect when writing with a computer was conducted. In order to better address the different areas in the problem earlier identified the researcher decided to divide the review of literature in five sub topics: a) using computers for writing in elementary schools, b) the use of computers to write by English as a Second Language students, c) motivational aspects of using computers to write, d) computer barriers to using computers, e) "Student as Authors" Project.

The researcher attempted with this design to provide the reader with a logistic before conducting and drawing conclusions for the actual research.

\section{$\underline{\text { Identification of Participants }}$}

Following West Virginia University Institutional Review Board for the Protection of Human Subjects requirements consent and assent forms were handed out to each 40 potential 
participants in this study. The fourth grade class was chosen to be part of this study due to its multicultural aspect, almost $12 \%$ of its students were ESL students, one of the greatest percentage in the school. The students who participated in this study were those who agreed to participate and who had permission from their parents. From 40 permission letters distributed 12 returned. Two of the twelve students were ESL students, one was an advanced English speaker the other was a Limited English Proficient Student according to the results of Woodcock-Munez Language Survey of a state standardized assessment test given to the school's ESL population at the beginning of 1999 school year. The ESL students were from China, and Switzerland. The researcher used many methods to motivate students to be part of the study, including going to the site to explain the research to the students, although students seemed to be interested in participating only 12 handed in the papers granting them permission to participate by their parents. It is important to note that this study does not aim to compare native-English-speaking and ESL speaking students but to describe their behavior and motivation when using the computer to write within the "Student as Authors" Project.

According to their teacher, all children that participated in this research had computer skills equivalent to fourth grade students. The students at Bald Eagle Elementary School have keyboarding classes and a required number of hours to be in contact with computer technology working on Reading and Math skills (Anita Nedeff, personal communication, May 10, 2000).

Two educators who were directly involved in the "Student as Authors" Project were also participants in this study. One was a Brazilian English as a Foreign Language teacher, who was taking part of the Council of International Program at West Virginia University in the semester in which the study was conducted. She has been teaching English as a Foreign Language in a private language institute in Brazil for more than twenty years. Currently she is the coordinator 
of the children program at the language institute where she works. Being an English a Foreign Language educator who focus area is the teaching to English for children, her placement was at Bald Elementary School, assisting the school's ESL educator in helping Limited English Proficient children to improve their English skills, as well as assisting the ESL educator to conduct the "Student as Authors" Project at the school, a task successfully accomplished by Paty, the Brazilian educator, according to Vera, the ESL educator.. The ESL educator, Vera, who was also a participant in this study has a Master degree in Reading. She is the creator of the "Student as Authors" Project. She has been teaching for 19 years, many of which as a Title I Reading Specialist. Currently she is the ESL educator for the county where this study took place. The names of the educators as well as the students mentioned throughout the research are fictitious in order to assure their anonymity in this study

\section{Setting}

This research was conducted at Bald Elementary School, located at North Central, West Virginia. This school has an approximate population of 220 students grades K to 5, with an average class size of 17.1 students per room. The school focused on keeping students up to date with technology, in order to have them better prepared to cope with the Information Age.

There is one computer per classroom in the first and second grades, one to two computers per classroom in the third grade, two to three computers per classroom in the fourth grade and three computers per classroom in the fifth grade. There is also one computer in the Special Education room, five in the Title I rooms, two in the main office, one in the library, three laptops, 25 in the computer lab and 30 DreamWriters (Anita Nedeff, personal communication, September 27, 1999). All computers but seven have access to the Internet (Anita Nedeff, personal communication, April 20, 2000). 
The school has as part of its Reading activities the "Student as Authors" Project implemented in 1998 at that school by Anita Nedeff, the creator of the Project.The students participating in this research used computers to write in the "Student as Authors" Project based on the needs of the writing assignment during the forty-five minutes of their Reading and Writing class or as part of assignment given by the fourth grade teacher. In the "Student as Authors" Project students use computers for editing and revising, for prewriting and writing they use paper and pencil. The majority of the students were introduced to the use of computers for drafting, revising and editing in the "Student as Authors" Project during 2000 school year calendar (Anita Nedeff, personal communication, April 20, 2000).

\section{$\underline{\text { Identification and Creation of Data Collection Instrument }}$}

The researcher after an extended literature review decided to conduct a qualitative and quantitative approach by choosing to have questionnaire and interview as the modes of data collection.

According to Fink and Kosecoff (1995), a survey is the most efficient way of collecting realistic data from people when the area to be studied relates to their feelings, motivation, behavior and attitude. A survey is usually constructed based on two different but closely related instruments: questionnaire and interviews (Bourque \& Fielder, 1995).

\section{Questionnaire}

The questions were adapted from the Motivation to Write Profile (Codling \& Gambrell, 1997), and Attitudes Toward Using Computers Survey (Warshcauer, 1996) taking into consideration Fink and Kosecoff (1995) statement that by basing the survey on surveys that have already been tested and validated ensures the reliability and validity of the survey. 
The researcher opted for having close-ended questions. All 15 questions were answered on a five-point Likert scale, with five being the highest score. Five of the questions were reverse coded. The use of reverse coded questions where students have to give a negative response to indicate a positive attitude was considered in order to avoid the tendency of students to choose all positive answers such as "Strongly agree" without thinking about what was asked or stated (See Appendix A).

Out of the 15 questions one addressed the importance of computers in the "Student as Authors Project", Research Question 1, the rest of the questions accessed the motivational aspects of using computers to write, Research Question 2. The items related to the motivational aspects of using computers to write addressed the quality of writing, feelings about writing on the computer, exposure of subjects' writing, quantity of writing, and preference of writing.

Bold face font was used to emphasize instructions or an important item in the text. The questions were organized in an easy to difficult progression following a logical order. Demographic questions relating to language and nationality were asked at the beginning of the questionnaire. The questionnaire contained a reminder of the confidentiality of the person's answers.

Smiley faces were used to represent the level of agreement with a statement. This design was chosen based on the participants' characteristics. If students had any doubt concerning the meaning of the word such as "Disagree" or "Strongly agree" they could use the smiley faces as a way to express their feelings and better react to what was being stated.

$\underline{\text { Interview }}$

As mentioned by Bourque and Fielder (1995) interviews provide in-depth information about a particular research issue or question. Literature shows that interviews differ from written 
questionnaire among other things by providing a situation where verbal data can be analyzed and studied taking on consideration context and physical reaction (Bourque \& Fielder, 1995; Fink, 1995).

According to Gall, Gall and Borg (1999) by using triangulation the researcher can compare results from findings to similar data collected at different time or in a different situation providing in this way different perspectives for the study being conducted.

In order to validate and support the findings of this study the researcher interviewed the school's ESL educator, the Brazilian EFL teacher, and 12 fourth grade students participating in the "Student as Authors". Two of the participants were ESL students. One was fluent in English while the other was Limited in some of her English skills. Due to the peculiarities of this study sample, the researcher considered that it was worth conducting an interview in order to give the students the chance to fully express themselves using different English skills. The questionnaire would provide the chance for those who are more visual to express themselves, whereas the interview would provide a better chance for those who are more oral to be understood in their statements.

The interview questions were open-ended. Privacy and confidentiality were assured. They were content interviews, therefore the data were tape recorded. The interviews followed an unstructured format allowing a more free flowing rather than a rigid structure (Bourque \& Fielder, 1995; Fink, 1995).

The interviews addressed the importance of computers in the "Students as Authors" Project, participants' feelings about writing on the computer, their likes and dislikes when writing on the computer, the exposure of subjects writing and the quantity of writing, and the subjects' preference of writing. The questionnaire and the interviews were submitted to the 
revision and approval of the committee members (see Appendix A, Appendix B and Appendix

C). The questionnaire and interviews followed the criteria mentioned by Fink and Kosecoff (1985) and Fink (1995).

The researcher went to the school and during the Reading and Writing class, the researcher explained the study to the students. The fourth grade teachers volunteered themselves to collect students' Consent and Assent forms. The researcher made sure that students understood that they were not going to be graded for participating in the study. Their participation would be volunteer and their names were going to be withheld from the public. The researcher waited two weeks for the returning of the Consent and Assent forms. Out of the 40 distributed 12 returned.

\section{Request of Permission to Conduct the Research}

After revision of the first three chapters of this research project and the approval by the members of the researcher's committee, an application for permission to conduct this research was submitted to the school's principal, the parents of the children involved in the research, the ESL educator of the county schools, and the Brazilian EFL educator, the Office of Human Subjects Committee of West Virginia University and to the Board of Education Office. Upon approval of all parties, the date for the data collection was established and the research progressed.

\section{$\underline{\text { Data Collection }}$}

\section{The Motivational Aspect of Using Computers to Write Questionnaire}

The questionnaire was conducted during Vera's class. In order to minimize the possibility of students giving answers that they believed were expected from them, students were pulled out of the class one by one. 
The questionnaire on Motivational Aspects of Using Computers to Write was distributed to each one of the 12 students one at a time. The researcher was available to help clarify any doubt concerning procedure or meaning that the students had. It took about 10 minutes for each of the 12 students to complete the questionnaire

The questionnaire was self-administrative, a term that is used to determine an instrument "used to collect information from people who complete the instrument themselves" (Bourque \& Fielder, 1995, p.2). The researcher read aloud the questionnaire questions and instructions making sure that the participants understood the contents. After filling out the questionnaire students were asked to put the questionnaire in an envelope available on the teacher's desk.

\section{$\underline{\text { Interview }}$}

The questionnaire and the interview were conducted on different days. Both were conducted after the students had been using the computers in the writing process for about three weeks. The interviews were face-to-face, one participant at a time, pulled from their writing class, the interview was conducted in the Title I room. It took about 10 minutes to interview each participant. The researcher made use of a tape recorder to keep track of the data. Written permissions were given by the participants and their parents or guardians. The investigator also asked for oral consent. Written and oral consents were also asked to the school's ESL educator, Vera, and the Council of International Program (CIP) 's participant, Paty, a Brazilian English as a Foreign Language Teacher. Paty was chosen to be interviewed due to her lack of previous involvement in the project and the fact of her being an EFL educator for twenty years. As a foreigner, her impressions of the project and of the students' reaction to the writing process on the computers were considered important to this research. Paty' interview was conducted after the students were writing one week on the computers. Vera was chosen to be interviewed based 
on her in-depth experience as an ESL educator and her direct contribution to the "Student as Authors" Project. As one of the creators of the project, Vera has a unique point of view concerning it which will enrich this study. Her interview was conducted near the end of the project.

All interviews were unstructured interviews. According to Bourque and Fielder (1995), this style gives you more chance of adjusting the questions according to the flow of the conversation.

The steps to conduct an interview according to Fink and Kosecoff (1995) were followed. First the researcher established a harmonic and non-threatening environment by informally talking to the interviewer. Second, the researcher described the purpose of the interview and stated the importance of the participants' responses to the research and to their school. The participants were asked permission to tape record their answers. The interviewer made sure that the participants were aware of the anonymous character of the interview and that they were not going to be graded on the interview questions.

\section{$\underline{\text { Data Analyses }}$}

The data collected in this research were analyzed in three particular ways. The data collected in the interview were analyzed by sorting the data from the interviews into categories. The data collected on the interviews of the ESL educator and the Brazilian EFL educator were submitted to their analyses. They reviewed the material for accuracy and palatability as it was suggested by (Gall et. al, 1999).

Due to the small size of the sample, a descriptive analysis was chosen as the best method of analyzing the Motivation to Write Aspect on Using a Computer questionnaire. 


\title{
CHAPTER IV
}

\author{
Analysis of Data
}

\section{$\underline{\text { Introduction }}$}

The purpose of this chapter is to analyze the data collected in the fall semester of 2000 at Woodburn Professional Development School. By analyzing the data, this research answered the following research questions: a) how do fourth grade students perceive the importance of the computer in the "Student as Authors" Project? and b) what are the motivational aspects of using the computer to write in the "Student as Authors" Project from fourth grade students' perspective?

This chapter is divided into the following sections: 1) modes of data analyses, 2) demographic data, and 3) analysis of data by research question.

\section{Modes of Data Analysis}

In order to answer these research questions, a questionnaire followed by an interview were used as means of data collection. The questionnaire used a five-point Likert scale where the lowest value attributed was 1 for "Strongly Disagree" and the highest value was 5 for "Strongly Agree". It was attributed value 2 for "Disagree", 3 for "Neutral" and 4 for "Agree"(See Appendix A and Table 1). Out of 15 questions, five were reversed and had to be interpreted in the opposite way of the other questions since students had to give a negative response to show a positive attitude toward computers. Therefore, in some questions to show a positive attitude concerning writing on computers students had to mark "Strongly Agree" and a value of 5 was attributed to it in the reversed questions in order to show a positive attitude concerning writing 
on computers students had to mark "Strongly Disagree" and a value of 1 was attributed to it.

Thus in items 1, 4, 6, 10, 14 the higher the value the higher the negative attitude concerning writing on the computers (see Appendix A and Table 1).

Table 1

$\underline{\text { Results of Questionnaire on the motivational aspect of using computers to write }}$

\begin{tabular}{|c|c|c|c|c|c|c|c|c|c|c|c|c|c|c|c|}
\hline & \multicolumn{15}{|c|}{$\underline{\text { Items }}$} \\
\hline Subjects & $* 1$ & 2 & 3 & *4 & 5 & ${ }^{*} 6$ & 7 & 8 & 9 & ${ }^{\star} 10$ & 11 & 12 & 13 & *14 & 15 \\
\hline 1 & 1 & 3 & 4 & 3 & 4 & 2 & 3 & 4 & 3 & 2 & 3 & 3 & 4 & 1 & 5 \\
\hline 2 & 1 & 5 & 4 & 1 & 5 & 1 & 3 & 5 & 5 & 1 & 3 & 5 & 5 & 1 & 5 \\
\hline 3 & 1 & 5 & 4 & 5 & 4 & 1 & 5 & 3 & 3 & 4 & 4 & 5 & 5 & 1 & 3 \\
\hline${ }^{\star *} 4$ & 1 & 4 & 4 & 2 & 4 & 3 & 4 & 3 & 4 & 2 & 4 & 4 & 4 & 2 & 4 \\
\hline 5 & 1 & 4 & 4 & 1 & 5 & 1 & 2 & 4 & 4 & 4 & 4 & 2 & 4 & 1 & 5 \\
\hline 6 & 1 & 5 & 4 & 4 & 3 & 1 & 5 & 3 & 3 & 4 & 3 & 4 & 5 & 1 & 2 \\
\hline 7 & 2 & 3 & 5 & 4 & 3 & 2 & 4 & 3 & 1 & 4 & 5 & 2 & 3 & 1 & 4 \\
\hline 8 & 3 & 4 & 4 & 4 & 3 & 2 & 4 & 2 & 2 & 2 & 4 & 4 & 2 & 2 & 2 \\
\hline 9 & 1 & 5 & 4 & 4 & 5 & 2 & 4 & 5 & 4 & 2 & 4 & 4 & 5 & 1 & 1 \\
\hline 10 & 2 & 4 & 5 & 3 & 4 & 2 & 4 & 3 & 3 & 3 & 3 & 4 & 3 & 2 & 4 \\
\hline 11 & 1 & 4 & 3 & 2 & 5 & 2 & 4 & 5 & 4 & 4 & 2 & 3 & 4 & 1 & 4 \\
\hline${ }^{* *} 12$ & 5 & 2 & 2 & 5 & 3 & 3 & 4 & 1 & 2 & 5 & 2 & 3 & 4 & 3 & 1 \\
\hline
\end{tabular}

\begin{tabular}{|l|l|l|l|l|l|l|l|l|l|l|l|l|l|l|l|} 
Mean & 1.67 & 4.00 & 3.92 & 3.17 & 4.00 & 1.83 & 3.83 & 3.42 & 3.17 & 3.08 & 3.42 & 3.58 & 4.00 & 1.42 & 3.33 \\
\hline
\end{tabular}

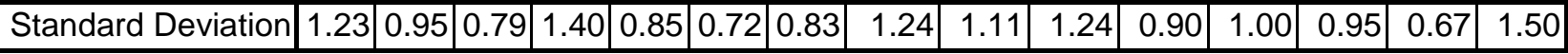

* These Items were structured in the opposite polarity than other items.

** ESL students

*** Answers ranged from 1 "Strongly Agree" to 5 "Strongly Disagree"

A descriptive analysis of the data was performed due to the small sample of this study.

The mean is the average resulted from the addition of the values ( 1 to 5) attributed to the subjects' answers in a particular item divided by the number of subjects, in this case 12 . The standard deviation "is a more stable and mathematically meaningful measure of variability. The standard deviation is a statistical expression of how much individual scores vary around the 
mean score" (Gall et al, pg. 152, 1999). The researcher based the analysis of this part of the data on the interpretation of the results found in the mean and standard deviation of each item.

Interview data were analyzed following the procedure suggested by Gall et. al. (1999).

First, the researcher transcribed the students' and educators' interviews verbatim. The researcher, then created a set of categories, most of them matched those created to analyze the questionnaire data. Finally the segments of the questionnaire and answers were then coded based on the categories in which they fit. New categories were created if the data did not fit in the preestablished ones. Students' interviews (See Appendix B) were analyzed first followed by the educators' interviews (See Appendix C and Appendix D). By having different data sources and two data collection methods, the researcher intended to have a triangulation increasing the validation of this study (Gall et. al, 1999).

\section{Demographic Data}

The population sample was composed of 12 fourth grade students and two educators. One educator was a Brazilian English as a Second Language and Foreign Language teacher and the other, an American Reading specialist and ESL educator. Out of the 12 students four (33\%) were boys, eight (66.7\%) were girls. Ten (93.3\%) were born in the United States, two (16.7\%) were ESL students. Five (41.7\%) were ten years old and seven (58.3\%) were nine years old (see Table 2). 
Table 2

\section{Demographic Data Chart}

\begin{tabular}{|c|c|c|c|c|}
\hline Subject & Age & Gender & $\begin{array}{c}\text { Country of } \\
\text { Birth }\end{array}$ & $\begin{array}{c}\text { Language } \\
\text { spoken in the } \\
\text { birth country }\end{array}$ \\
\hline 1 & 10 & Boy & U.S.A. & English \\
\hline 2 & 9 & Boy & U.S.A. & English \\
\hline 3 & 9 & Girl & U.S.A. & English \\
\hline 4 & 10 & Girl & China & Chinese \\
\hline 5 & 9 & Girl & U.S.A. & English \\
\hline 6 & 9 & Girl & U.S.A. & English \\
\hline 7 & 10 & Boy & U.S.A. & English \\
\hline 8 & 9 & Girl & U.S.A. & English \\
\hline 9 & 9 & Girl & U.S.A. & English \\
\hline 10 & 10 & Boy & U.S.A. & English \\
\hline 11 & 9 & Girl & U.S.A. & English \\
\hline 12 & 10 & Girl & Switzerland & German \\
\hline
\end{tabular}

\section{Discussion of Research Question 1}

The first research question answered by this study was: How do fourth grade students perceive the importance of computers in the "Student as Authors" Project? The following results were gathered.

Questionnaire:

Out of the fifteen questions asked in the questionnaire, only one question addressed Research Question 1, item 3, “I think computers are very important in Mrs. Nedeff's class”. For this specific item, the mean score was 3.92 with a standard deviation of 0.79 .

\section{Students' Interview:}

Interview questions were asked to also answer Research Question 1, about the importance of computers. Three questions were asked about this category. Throughout the 
interview, seven subjects considered computers important in the "Student as Authors" Project. When asked about their perception of the value of the "Student as Authors" Project without the presence of a computer eight out of the twelve students reacted by suggesting that the Project's main focus, which is creative writing, would be the same but the fun and enjoyment of the Project would be affected by not having computers as part of it. When asked how different would the Project be without the presence of computers Eric, contested 'it wouldn't be as fun, I can tell you that it really would be a boring class [cause] it just writing everything". Sandra, expressed her feelings toward this question by stating “... it wouldn't be so different but I really like using the computer." Dara, added to this thought by saying, "I think it would be a lot different because we wouldn't be able to type out things and we would, we would [just to have] to write it down on paper. I think it would be less fun."

Two of the subjects considered computers very important and when asked about the feelings toward the possibility of not having the computers as part of the "Student as Authors" Project, one of them, Rodrigo described it by using a simple sentence to answer this question" I don't know... mad", further he explained that the reason for being so was the fact that he preferred to write on the computers instead of handwriting. The other, Ana, reacted to this question by saying "I would not be very happy." There was one "neutral" position hold by Marina who stated, “It wouldn't exactly bother me because, like, I said, I don't really care whether I am writing on pencil and paper or on computer. It wouldn't make a difference to me but it might to other people, you know, this is just my opinion." 
One out of the twelve subjects interviewed showed a negative attitude concerning the use of computers in the project when asked about not having a computer as part of the project, Judy reacted by stating that it would be a lot better.

The two ESL student participating in this study had completely different perceptions about the importance of computers in the project while Amanda thought that computers were important in the project Judy was emphatic in stating that computers were not that important in the project.

\section{$\underline{\text { Educators' Interview }}$}

Paty and Vera were asked two questions in order to answer Research Question 1. When asked about the importance of computers in the "Student as Authors" Project, Paty saw the computer as a facilitator in the writing process due to the students' facility in editing and revising their work and the computers' storage feature, “... they go to the computer and they are not supposed to have a final work. They can go and review and delete and go back and even change their work, so this flexibility is something that really let them free to write, and rewrite."

Vera declared that she considers computers important in the "Student as Authors" Project for two main reasons: students enjoy writing on the computer, resulting in longer writing samples and it makes it easier for the educator to give feedback on the printed copy of the students' work.

... I consider it (computer) very important... the children wrote longer passages they use more complex sentences, uh, they didn't find it so tiring and it was just far more enjoyable... for me computers are valuable because it's difficult to read children's writing sometimes... when it's a hard copy printed out by computer, 
you know, by a printer then I can make it out a little easier and have room for editing and everything, so it just makes it easier for me.

As a follow-up question, Paty and Vera were asked what the project would be like without the presence of a computer. Paty emphasized that the project would still achieve its goals but students would not be so motivated towards the Project,

I believe that they would finish their work anyway but the excitement of writing more because they had the chance of typing would be gone... having the DreamWriter itself in their own room and storing their own files made the whole difference... Typing together was really more than a plus it was very important for the whole project. I can't see taking the DreamWriter from the project.

The project would only be different in that the children would be complaining about having to make the revisions and edit and their copy over the final draft ... they don't mind copying over a poem but a short story or something like that can be very tedious.

\section{Discussion of Research Question 2}

The second question answered by this study was: What are the motivational aspects of using a computer to write in the "Student as Authors" Project, from fourth grade students' perspective? The following results were gathered based on the results of the mean and standard deviation of each item.

\section{Questionnaire}

Out of the fifteen questions asked in the questionnaire fourteen items (except number 3) were designed to answer the second research question. Five were reversed questions $(1,4,6,10$ and 14). For a better understanding, the items were divided into four categories: a) quality of 
writing, b) feelings about writing on the computers, c) exposure of subjects' writing, d) quantity of writing, and e) preference of writing.

Items 2, 6, and 11 addressed students' perception of the quality of their writing when using a computer as a motivational aspect for writing on the computers. The results were as follow. Item 2 "I think computers help me to write better" mean score was 4.00 with a standard deviation of 0.95 . Item 6 "When I write on the computers my stories are poor" was a reversed question and its mean score was 1.83 with a standard deviation of 0.72 . Item 11 "I make more changes in my stories when I write on the computer" mean score was 3.42 with a standard deviation of 0.90 (See Table 3).

Table 3

Quality of Writing

\section{Items}

\begin{tabular}{|c|c|c|c|}
\hline Subjects & $\mathbf{2}$ & ${ }^{*} \mathbf{6}$ & $\mathbf{1 1}$ \\
\hline $\mathbf{1}$ & 3 & 2 & 3 \\
\hline $\mathbf{2}$ & 5 & 1 & 3 \\
\hline $\mathbf{3}$ & 5 & 1 & 4 \\
\hline${ }^{\star *} \mathbf{4}$ & 4 & 3 & 4 \\
\hline $\mathbf{5}$ & 4 & 1 & 4 \\
\hline $\mathbf{6}$ & 5 & 1 & 3 \\
\hline $\mathbf{7}$ & 3 & 2 & 5 \\
\hline $\mathbf{8}$ & 4 & 2 & 4 \\
\hline $\mathbf{9}$ & 5 & 2 & 4 \\
\hline $\mathbf{1 0}$ & 4 & 2 & 3 \\
\hline $\mathbf{1 1}$ & 4 & 2 & 2 \\
\hline${ }^{\star \star} \mathbf{1 2}$ & 2 & 3 & 2 \\
\hline
\end{tabular}

\begin{tabular}{l|l|l|l|} 
Mean & 4.00 & 1.83 & 3.42 \\
\hline
\end{tabular}

\begin{tabular}{|l|l|l|l|}
\hline Standard Deviation & 0.95 & 0.72 & 0.90 \\
\hline
\end{tabular}

* These Items were structured in the opposite polarity than other items.

** ESL students

Items $1,5,14$ and 15 were related to the subjects' reaction concerning writing on the computer. Out of the four items two were reversed questions. Item 1 "I hate using computers to 
write" was a reversed question and had a mean score of 1.67 with a standard deviation of 1.23. Item 5 "Writing on the computer is a lot of fun" mean score was 4.00 with a standard deviation of 0.95 . Item 14 "Computers make writing boring" was an opposite polarity question, and had a mean score of 1.42 with a standard deviation of 0.67 . Item 15 "Writing on the computers is the best part of Mrs. Nedeff's class" mean score was 3.33 with a standard deviation of 1.50 (See Table 4).

\section{Table 4}

Feelings About Writing on the Computer

\section{Items}

\begin{tabular}{|c|c|c|c|c|}
\hline Subjects & ${ }^{*} \mathbf{1}$ & $\mathbf{5}$ & ${ }^{*} \mathbf{1 4}$ & $\mathbf{1 5}$ \\
\hline $\mathbf{1}$ & 1 & 4 & 1 & 5 \\
\hline $\mathbf{2}$ & 1 & 5 & 1 & 5 \\
\hline $\mathbf{3}$ & 1 & 4 & 1 & 3 \\
\hline${ }^{*} \mathbf{4}$ & 1 & 4 & 2 & 4 \\
\hline $\mathbf{5}$ & 1 & 5 & 1 & 5 \\
\hline $\mathbf{6}$ & 1 & 3 & 1 & 2 \\
\hline $\mathbf{7}$ & 2 & 3 & 1 & 4 \\
\hline $\mathbf{8}$ & 3 & 3 & 2 & 2 \\
\hline $\mathbf{9}$ & 1 & 5 & 1 & 1 \\
\hline $\mathbf{1 0}$ & 2 & 4 & 2 & 4 \\
\hline $\mathbf{1 1}$ & 1 & 5 & 1 & 4 \\
\hline${ }^{*} \mathbf{1 2}$ & 5 & 3 & 3 & 1 \\
\hline
\end{tabular}

\begin{tabular}{|c|c|c|c|c|}
\hline Mean & 1.67 & 4.00 & 1.42 & 3.33 \\
\hline $\begin{array}{c}\text { Standard } \\
\text { Deviation }\end{array}$ & 1.23 & 0.95 & 0.67 & 1.50 \\
\hline
\end{tabular}

* These Items were structured in the opposite polarity than other items.

** ESL students

Items 7, 12, and 13 addressed subjects' reaction to the exposure of their writing on the computer. Item 7 "I like to have people read what I write on the computer" mean score was 3.83 with a standard deviation of 0.83 . Item 12 "I like to know that great number of people can order my stories on the net" mean score was 3.58 with a standard deviation of 0.90 . Item 13 "Knowing 
that my work is going to be published or turned into an electronic book motivates me to write" mean score was 4.00 with a standard deviation of 0.95 (See Table 5).

\section{Table 5}

Exposure of Subjects' Writing

\section{Items}

\begin{tabular}{|c|c|c|c|}
\hline Subjects & $\mathbf{7}$ & $\mathbf{1 2}$ & $\mathbf{1 3}$ \\
\hline $\mathbf{1}$ & 3 & 3 & 4 \\
\hline $\mathbf{2}$ & 3 & 5 & 5 \\
\hline $\mathbf{3}$ & 5 & 5 & 5 \\
\hline${ }^{\star *}$ & 4 & 4 & 4 \\
\hline $\mathbf{5}$ & 2 & 2 & 4 \\
\hline $\mathbf{6}$ & 5 & 4 & 5 \\
\hline $\mathbf{7}$ & 4 & 2 & 3 \\
\hline $\mathbf{8}$ & 4 & 4 & 2 \\
\hline $\mathbf{9}$ & 4 & 4 & 5 \\
\hline $\mathbf{1 0}$ & 4 & 4 & 3 \\
\hline $\mathbf{1 1}$ & 4 & 3 & 4 \\
\hline$\star \mathbf{1 2}$ & 4 & 3 & 4 \\
\hline
\end{tabular}

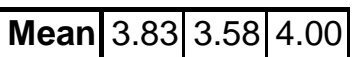

\begin{tabular}{l|l|l|l|}
\hline Standard Deviation & 0.83 & 1.00 & 0.95 \\
\hline
\end{tabular}

* These Items were structured in the opposite polarity than other items.

** ESL students

Items 9 and 10 consider the subjects' perception of the amount of writing done when

using the computer. Item 9 "Computers make me want to write more" mean score was 3.17 with a standard deviation of 1.11. Item 10 "I write less when I write on the computer" was an opposite polarity question and had a mean of 3.08 with a standard deviation of 1.24 (See Table 6). 


\section{Table 6}

\section{Quantity of Writing}

\begin{tabular}{|c|c|c|}
\multicolumn{2}{c}{} & \multicolumn{2}{c|}{ Items } \\
\hline Subjects & $\mathbf{9}$ & ${ }^{*} \mathbf{1 0}$ \\
\hline $\mathbf{1}$ & 3 & 2 \\
\hline $\mathbf{2}$ & 5 & 1 \\
\hline $\mathbf{3}$ & 3 & 4 \\
\hline${ }^{*} \mathbf{4}$ & 4 & 2 \\
\hline $\mathbf{5}$ & 4 & 4 \\
\hline $\mathbf{6}$ & 3 & 4 \\
\hline $\mathbf{7}$ & 1 & 4 \\
\hline $\mathbf{8}$ & 2 & 2 \\
\hline $\mathbf{9}$ & 4 & 2 \\
\hline $\mathbf{1 0}$ & 3 & 3 \\
\hline $\mathbf{1 1}$ & 4 & 4 \\
\hline${ }^{*} \mathbf{1 2}$ & 2 & 5 \\
\hline
\end{tabular}

Mean $3.17 \quad 3.08$

\begin{tabular}{|l|l|l|}
\hline Standard Deviation & 1.11 & 1.24 \\
\hline
\end{tabular}

* These Items were structured in the opposite polarity than other items.

** ESL students

Items 4 and 8 were related to subjects' preference for a certain tool for writing.

Computers and paper and pencil were chosen as the tools from which subjects demonstrated their preference. Item 4 "I prefer to write without the help of a computer" was an opposite polarity question and had the mean score of 3.17 with a standard deviation of 1.40 . Item 8 mean score was 3.42 with a standard deviation of 1.24 (See Table 7). 


\section{Table 7}

Preference of Writing

\begin{tabular}{|c|c|c|}
\multicolumn{2}{c}{} & \multicolumn{2}{c|}{ Items } \\
\hline Subjects & ${ }^{*} \mathbf{4}$ & $\mathbf{8}$ \\
\hline $\mathbf{1}$ & 3 & 4 \\
\hline $\mathbf{2}$ & 1 & 5 \\
\hline $\mathbf{3}$ & 5 & 3 \\
\hline${ }^{\star \star} \mathbf{4}$ & 2 & 3 \\
\hline $\mathbf{5}$ & 1 & 4 \\
\hline $\mathbf{6}$ & 4 & 3 \\
\hline $\mathbf{7}$ & 4 & 3 \\
\hline $\mathbf{8}$ & 4 & 2 \\
\hline $\mathbf{9}$ & 4 & 5 \\
\hline $\mathbf{1 0}$ & 3 & 3 \\
\hline $\mathbf{1 1}$ & 2 & 5 \\
\hline${ }^{\star *} \mathbf{1 2}$ & 5 & 1 \\
\hline
\end{tabular}

\begin{tabular}{l|l|l|} 
Mean & 3.17 & 3.42 \\
\hline
\end{tabular}

\begin{tabular}{|l|l|l|}
\hline Standard Deviation & 1.40 & 1.24 \\
\hline
\end{tabular}

* These Items were structured in the opposite polarity than other items.

** ESL students

\section{$\underline{\text { Students' Interview }}$}

To better address research question 2 the researcher divided the data from the interviews into four categories. These categories matched the ones created to analyze that data from the questionnaire. Only one out of the five categories created to analyze the questionnaire data was not covered in this mode of data collection. The categories of the students' interviews are a) feelings about writing on the computers, b) likes and dislikes when writing on the computer, c) exposure of subjects writing and quantity of writing, and d) preference of writing.

Feelings about writing on the computers. Subjects were asked an average of three questions toward this category. When asked to describe their feelings towards writing on the computer seven subjects used the work "fun." They further explained their feelings by giving different reasons to consider computers fun. For them writing on the computer was fun because 
they liked to type, they thought that computers made them more creative and gave them time to think and plan on their writing, they enjoyed the DreamWriter, and the fact that it was something new for them and that computers made their writing neater and easier to read.

Among the ones who considered computers fun because they liked to type were George, Rodrigo, and Dara. When asked about their feelings about writing on the computer George stated "I like it because it's fun sometimes because you can use the keyboard and not, like, handwrite on the paper." Rodrigo added by saying: "I like it, because I like to type." Dara thought that computers were fun for two reasons because,

... you can type instead of writing using your hands... get tired just sitting there writing, and makes you, kike more creative I think because, sort of, when you are on the computer you don't have to, like, to sit down and think it just kind of comes all out because you are having more fun.

Ana thought computers were fun because "you got to take your time and got to kind of plan on the computer, and that was fun." Eric had the DreamWriter as the reason for thinking that writing on the computer was fun "that was really fun [cause] the DreamWriter is really cool!" Connie added to this thought by saying, "Every time we got to use the DreamWriter I would say, “Oh, I can't wait, I can't wait, I can't wait!” she then concluded her thoughts by adding another reason for thinking that computers were fun "it doesn't take long when you have to write a good report..."

On the other hand, Judy did not have fun or even like to use the computer to write she expressed her thoughts about the issue by saying, "I thought it was senseless because... uh, we already have them on paper so can't we just use these? ... and it takes a lot of time to type for fourth graders, you know." 
The ESL subjects who were interviewed expressed radically different opinion about the subject. While Amanda liked to use the computer to write and thought is was fun Judy thought that it was "senseless". Judy was the only subject who showed a great dislike for writing on the computers.

As a follow-up question students were asked if they thought computers helped them to write. The overall answers for this question were positive ones but the reasons differ among subjects. Subjects felt that computers helped them to write because it made the writing process more real since they went through the same process that a poet goes through when writing and publishing his/her poems. They felt that they could organize their ideas better and be more creative. The majority of the participants perceived computers as being easy to use, and it made the class more exciting besides preparing them for today's world.

To better understand the reason stated before some to the subjects' answers for this matter are presented as follow: George felt that computer helped him to write because, "I learn how to write on the computer for me is like grow up... say if you want to be, like, a poet ant you want to write on the computers instead of writing on paper it helps you to learn how to write on the computers."

Dara had a different perspective in how computers helped her to write as she stated "I think they helped me, like, get my ideas to write and when I am typing on the computer I think more about what I am writing." Amanda, Ana, and Sandra had the impression that computers were easy to use and helped them to write more and neater. When asked about how computers helped them to write Amanda replied, “... it helped me to write more and read." Ana, added to this comment by saying “... you get done a lot neater and people [could] read it” Sandra finalized the thought by saying "I think it really helped me because it is really easy to use..." 
Eric pointed out that computers were a key part of motivation "[...] mainly it [make] it more exciting so I felt better about the class and it helped me work better."

The ESL learners Amanda and Judy had again different opinion about the question. While Amanda had the opinion that computers helped her to write more, Judy denied that computers helped in her writing process.

The last question in this category was a very general question. Subjects were asked what the best part of the Reading and Writing class was, among the twelve interviewed subjects, six spontaneously said that it was writing or typing on the computer. For instances, when asked to name the best part in the Reading and Writing class Rodrigo replied "when we got to use the DreamWriter" so did Ana whose answer to the question was "writing on the computer".

Likes and dislikes about writing on the computer. Subjects were asked what they liked most about writing on the computer. The answers for this particular question varied. Subjects most common answer were that they enjoyed to get to type and to use the DreamWriter, they also suggested that the possibility of having their work printed was one of the things that they appreciated when using computers. Others pointed out that the reading process was easier on the computer since as mentioned by some they did not have to be worried about having a nice handwriting to share their piece of writing with others. Amanda stated in her interview that the best part of writing on the computer was "to type" while Ana considered printing her work the best in using computers “... our poems got to be printed and we've got to read it and just take our time and have fun". On the other hand, Eric listed the use of the DreamWriter as his favorite part about writing on the computer, "I like it because of the thing we were typing on, you know, it is not exactly a computer it is like a typewriter thing, it is like a mechanical typewriter, it is 
really neat." Rodrigo added up to the list of best things about writing on the computer by stating "It makes your handwriting neater."

Between the two ESL students of this group the opinions once more were different while one loved to type on the computer, Amanda, the other, Judy did not like using the computer to write at all.

However, when asked about what they did not like about writing on the computer the two ESL student agreed on their point of view. While Amanda stated, "I didn't like to type wrong", said, "typing and not knowing how to do certain things like how to get into your file, and stuff, and... uh, getting back and [have] your writing deleted."

Two other subjects complained about the lack of typing skills. Herval and Ana did not enjoy the spell check feature. The limitations of the DreamWriter was pointed out by Fabricia whose love for drawing could not be explored on the computer. A disturbing DreamWriter's feature was pointed by Sandra. According to her there is a feature in the DreamWriter for keeping track of the typing ability of the person using the DreamWriter, "I did not like anything except computers [keep target] me on how well I was writing and so... I got, like, to the ninety six and I am, like, I don't like it anymore, but I wanted to still type because I was really concentrate on it... some people just [speed up]"

Eric had the feeling that it took too long to finish his work when writing on the computer “...it just took you long, it took us, like three weeks to finish them.” George, Dara and Connie were very enthusiastic about writing on the computer reporting that they liked everything about writing on the computer. For George, the worst part about writing on the computer was "when we had to print and stop." 
Exposure of subjects writing and quantity of writing. When asked about the exposure of their writing and the quantity of writing two subjects spontaneously commented that they liked to have their work printed out. Connie stated that it was "easier to share her work since she did not have to worry about her handwriting." When questioned if computers made them write more four of the subjects declared that they wrote more on the computers. For Dara computers helped her to write more because "... it gives, like, when I am on the computers it is more fun for me and it gives me just a little bit more ideas", while the reason given by Fabricia was that it made her revise what she has written making her to reflect on her writing and enhance it resulting in most of the times in a longer writing sample. On the other hand, six of the subjects did not think that they wrote more on the computer. Connie reported, "with paper and pencil I usually write a little bit more" and Judy when asked the same question declared, "Actually, I write less."

Preference of writing. Subjects were asked to choose their preference between writing on computers or pencil and paper, eight subjects out of twelve expressed their preference for the use of computes to write. Among the reasons reported by them were that computers were fun, they enjoyed typing and that computers made the writing process easier. For instance, Herval, declared that to write on the computer "was sort of pretty fun and a little bit nicer than writing on regular paper". For Amanda writing on the computer was worthy because she got to type. In Rodrigo's opinion the reason for choosing computers over pencil and paper was that "computers make things easier" on the other hand, three subjects declared that they preferred to write on paper and pencil. The reasons given were concerning environmental concerns as it could be found in Marina's observation “... I just prefer to write with paper and pencil than on the computer because, I mean, this probably is not the time to say this but Americans use forty 
percent of all the natural resources of technology and I'd rather use my body works than technology." The other reason given by Judy was that writing on computers was "senseless".

As a follow-up to the question, the researcher asked subjects to express their opinions about having all the writing process using computers, not using paper and pencil in any instance. Five out of the twelve subjects answered to the question saying that they would enjoy the experience. Dara emphasized that the revision process would be easier but it would take longer to finish the work, "I think it would be fine but it would be a lot of hard work because if you are on the computer you might want to think "oh, I made a mistake and I can just delete it and it won't make any difference" so I think it would turn out a little better."

Eric commented that the editing process would be easier "Ah, sometimes we make so many mistakes on the computer that it doesn't matter on draft so I prefer the computer to draft". Sandra remarked that she would enjoy having to write everything on the computer but she "would get a little tired of the computer".

Seven of the twelve subjects revealed a negative feeling concerning writing without using paper and pencil but when asked the reason most of them could not express it into words. Fabricia was one of the few who gave a reason for her disapproval of using only computers. Fabricia is artistic and computers did not allow her to draw, which gave her enough reason of wanting to have paper and pencil as part of the writing process. Although having a different perspective of the use of computers on the writing process Amanda and Judy agreed that paper and pencil was the best technology to use for drafting purpose.

\section{Educators' Interview}

To better understand the data related to Research Question 2 the researcher categorized the questions into: a) advantages and disadvantages of writing on the computer, b) DreamWriter 
vs. Computer Lab, c) students' attitude when writing on the computer, and d) ESL and native English speaking students' reaction to writing on the computer. Most of these categories data match the students' interview data analyzed previously.

Advantages and disadvantages of writing on the computer. Among the advantages to use the computer to write reported by the two educators were the editing and revising process considered to be easier on the computer and the enhancement in students' motivation. Vera stated,

It is not too tedious and it is a fun enjoyable way to write. Uh, it makes it easier when you word process the drafts to take the critiques from your peers and your teachers and make the revisions and then, go to the editing process and save, because paper and pencil means that you have to do that two or three times, and it is very tedious for them.

On the other hand, when asked about the disadvantages of writing on the computer Vera observed that the DreamWriter used a battery as its main source of energy and having to worry about recharging the batteries after using was a negative point on using the DreamWriters, also the lack of a diskette drive made saving a very complicated issue.

The disadvantages of using the DreamWriter was that they are battery charged and that each child had a certain number and if that number had a low battery that day it meant that some had to depend on their peers ... when it was time in the class to save their work, and they've been taught, some of them were so excited about what they were doing that they forgot to save it and the next time that they turned on the DreamWriter, their work would not be there... a teacher can't even 
use a backup disk with the DreamWriter and say "well here I'll put this and I'll have it", if the students did not save then the work would not be there.

Paty considered the lack of prior keyboarding experience a disadvantage when students were composing on the computer,

I think we should give them further instructions in typing because they were really excited about he DreamWriters at a certain point they had some difficulties in typing and they were a little bit anxious about that, some of them were a little bit faster, we could reach everybody at the same level of typing speed, we could empower them with some more instructions about that.

DreamWriter vs. computer lab. The fact that students were using a DreamWriter instead of going to the computer lab to type their work was considered by Vera and Paty as an important motivational part of the whole project. Vera claimed, "the DreamWriter was far more exciting because it wasn't a desktop, everybody had one to use in their room and it was to them kind of a laptop and that was exciting." Paty declared that when she first saw the DreamWriters she questioned about the validity of using it since there was a computer lab in the school but she changed her opinion later when she realized that the students felt really comfortable writing on the DreamWriter and seeing it as a way of playing during class hours. At that point for Paty writing became part of their leisure activities.

... they kind of detached themselves from this idea that computers are something serious for adults, that they could mess it up, the feeling was that it was something that they could do it. It was something made for them. So they felt comfortable and less anxious ... it was more like a toy and a tool so while they were on the computer they felt comfortable they could rewrite and play with what they were 
doing ... it was incredible how excited they were about that because it looks like a toy and I caught them saying "I wish I could have one of those at home so that I could write more poems". Writing poems became something that they wanted to do for fun and not just an assignment in the classroom ... the DreamWriter was a plus.

Students' attitude when writing on the computer. Vera and Paty, reported that the overall attitude of the students toward writing on the computer was a positive one. Students who were more familiar with computers would help those who were not familiar with word processing fostering collaboration in the class. Moreover, students' sense of importance increased, as well as their willingness to write. Furthermore, students felt more motivated to edit their poems and spent their free time working on their poems on the computer.

Vera stated that some students, stayed during recess, some of them gave up morning time to finish their work on the DreamWriter, and lots of teachers talked about that... it was very nice to observe their reaction on the computer itself. They felt important and then, they felt like writing. The best part of it was to see that they felt important... students were really excited... students who didn't have the poems felt like they were going to miss the chance of typing their own poem and they felt excluded from the group and they didn't want to, the commitment to the whole project came when they saw the DreamWriter and they saw their work, then I heard students saying "I have to catch up, I have to take part of it".

ESL and native English speaking students' reaction to writing on the computer . Both Vera and Paty declared not to have observed any significant difference between ESL and native 
English speaking attitude when writing on the computer, "I could not see any difference between ESL and native speaking students, they could understand what they were doing so I could not spot any difference between their reaction and the others neither positive nor negative." 


\section{CHAPTER V}

Summary, Conclusion, and Recommendations

\section{Statement of Purpose}

The problem of this research was to describe the motivation to write when using computers by fourth grade elementary students participating in the "Student as Authors" Project at Woodburn Elementary Development School. The following questions were answered in this research: 1) How do fourth grade students perceive the importance of computers in the "Student

as Authors" Project? and 2) What are the motivational aspects of using a computer to write in the “Student as Authors" Project from fourth grade students' perspective?

\section{$\underline{\text { Summary of Findings }}$}

As a result of the data analysis, the following findings were determined:

Fourth grade students perception of the importance of computers in the "Student as Authors"

\section{Project: Research Question 1}

Data obtained revealed that students consider computers important in the "Student as Authors" Project due to the fun and enjoyment that they add to the Project, however, the absence of it is not seen as a barrier for the accomplishment of the "Student as Authors" activities and goals. The two educators interviewed in this research shared this opinion, but they also considered the editing feature a very important aspect when considering the importance of computers in the Project. This special feature was overlooked by the student when answering the research questions. The two ESL students presented different points of view regarding to the importance of computers in the project. While one felt particularly enthusiastic about using the computer, the other saw the computers as a negative part in the "Student as Authors" Project. 
The motivational aspects of using a computer to write in the "Student as Authors" Project, from fourth grade students' perspective: Research Question 2

Data analysis showed that the majority of students believed that computers helped them to write better and some mentioned that their writing was neater and easier to read. In their opinion, the computer helped them organize their ideas resulting in more creativity in the writing process, it also gave them more time to think and plan on their writing.

The data collected indicated that all students but one considered writing on the computer fun because they liked to type, and they enjoyed the DreamWriter, but they did not consider a problem of using the computers in the computer lab to type if needed. On the other hand, educators considered the DreamWriter an important part of the whole project. According to the educators, the DreamWriter was considered a toy by the students due to its shape and features, motivating them to use it without fear.

Half of the students that were interviewed considered writing on the computers the best part in the Reading and Writing class, while the other half considered other different aspects of the "Student as Authors" Project as their favorite part in the Reading and Writing class. For the educators students sense of importance increased with the use of computers to write since they started to see themselves as "real" writers. Thus, students became more motivated to write and edit their work.

The data also demonstrated that students considered the possibility of having their work published and turned into a book a motivation aspect to write. Students declared that they enjoyed having their work printed and sharing their work for feedback. Students felt that computers helped them to write because it made the writing process more real since they followed the same procedures as real writers usually do. 
According to the data results although the majority of the students preferred to write on computers over paper and pencil. They also expressed a strong feeling against having the whole writing process on the computers. They indicated as some of the disadvantages of using a computer to write: their lack of typing skills, the "annoying" feature of the DreamWriter that kept track of students keystrokes and typing speed, the difficulty to store their work and the fact that they could not use the computer to draw. For the educators who were interviewed the disadvantages of using the computers to write were also the students' lack of typing skills and the difficulty of saving students' work as well as the fact of having to recharge the DreamWriter's battery.

Concerning the two ESL students participating in this research, the data showed that they had different opinions about every subject addressed by the researcher while one had an extremely positive attitude towards writing on the computer the other hated to have computers as part of the writing process.

\section{$\underline{\text { Conclusions }}$}

Considering the small sample size, twelve participants, the results drawn from this study should be considerate as preliminary until further research is done.

The following conclusions were drawn from this study:

1) Students considered computers important in the "Student as Authors" Project. The main reason given by the students to consider computers important was because students had fun typing on the computer.

2) Students considered the editing to be easy on the computer and the fact that they were doing everything that a writer does in order to have his/her work published as motivating 
aspects of writing on the computer. Having fun on typing on the computer was considered the major motivational aspect of using computers to write.

3) The lack of typing skills and selected features of the DreamWriter, were some disadvantages pointed out by the students.

4) Students considered writing on paper and pencil as important a writing on the computer. They liked the combination of both in the project, but they did not like the idea of having only one of the two tools for writing in the Project.

\section{$\underline{\text { Implications }}$}

The implications that were drawn from the results of their study focused on schools using computers as part of their writing projects.

- Teachers should consider students' typing skills before introducing them to a writing unit where computers are going to be used. Students should have keyboarding skills before starting any writing project. In this way students can focus on the content of their writing instead of on the mechanics involved in the typing process.

- Students have different learning styles, making available a number of features on the computer, as the possibility of drawing could broader the range of students who identify with technology and use it in a way that is meaningful to them.

- Although this study showed that students considered paper and pencil the preferred means of drafting, in today's world there is a tendency of going through all of the steps of writing on the computer. Schools should think about introducing the logistic behind the different steps of the writing process on computers, thus resulting in students who would have an easier adaptation to higher education writing needs. 


\section{$\underline{\text { Recommendations for Further Study }}$}

The following recommendations for future study are suggested:

1) A study focusing on ESL attitudes toward writing on computers in the "Student as Authors" Project could be done since the small sample of the ESL population participating in this study could not lead to any meaningful conclusion.

2) An actual field study could be done by having students using only computers to write in the "Student as Authors" Project, comparing then the results with those found in this research.

3) Another study could be done comparing the use of the DreamWriter vs. Computer lab in the "Student as Authors" Project, since students' and educators' opinions differed on this subject. 


\section{REFERENCES}

Arnore, M. P., \& Small, R. V. (March/April, 1999). Evaluating the motivational effectiveness of children's websites. Educational Technology, 39, 51-55.

Bacon, J. (1998). Transition (book review) teaching writing in computer supported and tradition classroom. Computers and Composition 15, 425-428.

Barksdale-Ladd, M. A. \& Nedeff, A. R. (1997). The world of a reader's mind: Student as authors. The Reading Teacher, 50, 564 -573.

Bicknell, J. (October, 1999). Promoting writing and computer literacy skills through studentauthored web pages. TESOL Journal, 53/4, 20-26.

Bourque, L. B, \& Fielder, E. P. (1995). How to conduct self-administered and mail survey. Thousand Oaks, CA: Sage Publications

Britsch, S. J., \& Berkson, R. (1997). “I am that...kid that acts weird:” Developing e-mail education in a third-grade classroom. Teaching Education, 8, 97-104.

Broomfield, H., \& Combley, M. (1997). Overcoming dyslexia: A practical handbook for the classroom. San Diego, CA: Singular Publishing Groups, Inc.

Brush, T. A. (1997). The effects of group composition on achievement and time on task for students completing ISL activities in cooperative pairs. Journal of Research on Computer in Education, 30, 3-17.

Chiero, R. T. (1997). Teachers' perspectives on factors that affect computer use. Journal of Research on Computer in Education, 30, 133-145. 
Codling, R. M., \& Gambrell, L. B. (1997). The motivation to write profile: An assessment tool for elementary teachers. National Reading Research Center: Instructional Resource, 38, 139.

Conte, C. (January, 1998). Technology in schools: Hip or hype?. The Education Digest, 63, 2833.

Cooley, V. E. (September, 1997). Empower teachers, power up technology. The Education Digest, 60 (2), 54-57.

Crook, C. (1994). Computers and the collaborative experience of learning. New York: Routledge.

Edbert, J., \& Hansom-Smith, E. (Eds). (1999). CALL environments: Research, practice, and critical issues. Blomington, IL: Teachers of English to Speakers of Other Language, Inc.

Fink, A. (1995). How to sample a survey. Thousands Oaks, CA: Sage Publications.

Fink, A., \& Kosecoff, J. (1985). How to conduct surveys: A step by step guide. Beverly Hills, CA: Sage Publications.

Fitzgerald, J. (1994). Crossing boundaries: What do second-language learning theories say to reading and writing teachers of English as a second language learners. Reading Horizons, $34,340-354$.

Gall, J. P., Gall, M. D., \& Borg, W. R. (1999). Applying educational research: A practical guide. New York: Addison Wesley Longman, Inc.

Gambrell, L. B., Morrow, L. M., Neuman, S. B. \& Pressley, M. (1999). Best practices in literacy instruction. New York: The Guilford Press.

Hawisher, G., \& Leblanc, P. (Eds). (1992). Re-imagining computers and composition. Teaching and research in the virtual age. Porsmouth, NH: Boyton/Cook Publishers. 
Hoffman, B. (January, 1997). Integrating technology into schools. The Education Digest, 62(5) $51-55$.

Jankowski, L. (1998). Educational computing: Why use a computer for writing? Learning and Leading with Technology, 25, 30-33.

Kahn, J. (1999). The same, but different: The computer as alternative medium. Learning and Leading with Technology, 26, 15-18.

Kang, S. \& Dennis J. R. (1995). The effects of computer-enhanced vocabulary lessons on achievement of ESL grade school children. Computers in the Schools, 11, 25-35.

Key, A. (1996). Revealing the elephant : The use and misuse of computers in education. Educom Review, 31, 22-26.

Knapp, R. L., \& Glenn, D. A. (1996). Restructuring schools with technology. Neidham Heights, Massachusetts: Allyn \& Bacon.

Kroll, B. (1990). Second language writing: research insights for the classroom. New York: Cambridge University Press.

Labbo, L. D., Reinking, D., \& Mckenna, M. C. (1999). The use of technology in literacy program. In Gambrell, L. B., Morrow, L. M., Neuman, S. B. \& Pressley, M. (Eds.), Best practices in literacy instruction. (pp. 311-327). New York: The Guilford Press.

Leu, D. J., \& Kinzer, C. K. (1999). Effective literacy instruction $\left(4^{\text {th }}\right.$ ed.). Upper Saddle River, New Jersey: Prentice-Hall, Inc.

Liu, L. \& Johnson, D. L. (1998). A Computer Achievement Model: Computer Attitude and Computer Achievement. Computers in the schools, 14, 33-54.

MarcArthur, C. A. (1999). Overcoming barriers to writing: Computer support for basic writing skills. Reading \& Writing Quarterly, 15, 169-192. 
Marcinkiewicz, H. R. (1994). Computers and teachers: Factors influencing computer use in the classroom. Journal of Research on Computer in Education, 26, 220-236.

Mergendoller, J. R. (April, 1997). Technology and learning: The research. The Education Digest, $62,12-15$

Merrill, P. F., Hammons, K., Vicent, B. R., Reynolds, P. L., Christensen, L., \& Tolman, M. N. (1996). Computers in education ( $3^{\text {rd }}$ ed.). Needham Heights, Massachusetts: Allyn \& Bacon.

Mitcham, C. (1994). Thinking through technology: the path between engineering and philosophy. University of Chicago Press: Chicago.

Mott, M. S., Sumrall, W. J., \& Hodges, M. L. (1997, November). Process and Computer-Based Elementary Writing Curriculum: A Review of Methods and Assessments. Paper presented at the Annual Meeting of the Mid-South Educational Research Association, Memphis, TN.

Nedeff, A. (1999). The "Student as Authors" Project. Retrieved from the web September 28: http//157.182.12.132/omdp/anita/html/st_auth.htm

Nedeff, A. R. (1997). "Student as Authors” project: authenticity in literacy. West Virginia English Journal, Spring, 17-23.

Nedeff, A., Brady, N., Maxwell, B., Oaks, R., \& Sechel, M. A. (1994). Students as authors. The Reading Teacher, 47, 349.

Nichols, L. M. (1996). Pencil and paper versus word processing : A comparative study of creative writing in the elementary school. Journal of Research on Computer in Education, $29,159-166$.

Oppenheimer, T. (1997). The computer delusion. The Atlantic Monthly, 280, 45-62. 
Owston, R. D. \& Wideman, H. H. (1997). Word processor and children's writing in a highcomputer-access setting. Journal of Research on Computer in Education, 30, 203-219.

Pennnington, J. R. (1989). Word processing and teacher evaluation. Electronic Learning, 3, 6682.

Pintrich, P. R. \& Schunk, D. H. (1996). Motivation in Education: theory, research and applications. Englewood Cliffs, New Jersey: Prentice Hall.

Raef, C. M. (1996). Improving student writing skills through the use of technology. Unpublished thesis dissertation, St. Xavier University.

Rose, R. J. (1989). Computer anxiety and hemispheric dominance. Unpublished doctoral dissertation, West Virginia University, West Virginia.

Rudden, J. F., \& Nedeff, A. R. (1998). ESL learners: process writing and publishing good literature. Reading Horizon, 38, 181-197.

Schurum, L., \& Berenfeld, B. (1997).Teaching and learning in the information age: A guide to telecommunications. Needham Heights, Massachusetts: Allyn \& Bacon.

Silva, T. (1993). Toward an understanding of the distinct nature of L2 writing. The ESL research and its implications. TESOL Quartely, 27, 657-677.

Smith, T. M. (1997). The pocket condition of education, 1997. Washington, DC: National Center for Education Statistics.

Solomon, G. (1986). Children, writing, and computers an activity guide. Englewood Cliffs, New Jersey: Prentice Hall.

Stronmmen, E. F., Lincoln, B. (1992). Construtivism, technology, and the future of classroom learning. Retrieved February 24, 1999 from the World Wide Web: http://www.ilt.colombia.edu/k12/livetext-nf/docs/construct.html 
Stuhlmann, J. M., \& Taylor, H. G. (1998). Analyzing the impact of telecommunication on learning outcomes in elementary classroom. Journal of Computing in Childhood Education, 9,79-92.

Tenner, E. (1997). Why things bite back: New York: Vintage.

The Institute for Social Research (1976). Interview's manual revised edition. Ann Arbor: Michigan.

U.S. Congress, Office of Technology Assessment, Teachers and Technology: Making the Connection, OTA-HER-616 (Washington, DC: U.S. Government Printing Office, April 1995).

Warshauer, M. (1996).Motivational aspects of using computers for writing and communication. In M. Warschauer (Ed.), Telecollaboration in foreign language learning. (pp. 29-46). Honolulu, HI: Second Language Teaching \& Curriculum Center (University of Hawai' I Press). Retrieved March 21, 99 from the World Wide Web:

http://www.1ll.hawaii.edu/nflrc/NetWorks/NW1/ 
APPENDICES 


\section{APPENDIX A:}

THE MOTIVATIONAL ASPECT OF USING COMPUTERS TO WRITE QUESTIONNAIRE 


\section{Motivational Aspects of Using Computers to Write Questionnaire}

\section{Do not write your name on this paper}

1) Please fill in the blank spaces with your personal information:

I am__ years old.
I was born in__ (boy/gir).
In the country that I was born people speak

2) Mark with an $X$ the best smiley faee that deseribes your feelings concerning theise of computer to write:

1) $t$ hate using computers to write.
16/ Strongly disagree
8) Disagree
(-) Neutral
(5) Agrec
(89) Strongly Agree

2) I think computers help me to write better.
2t/ Strongly disagree
(2) Disagree
(i) Neutral
(8) Agree
(2) Strongly Agret

3) It think computers are very important in Mrs. Nedeff's writing elass.
af/ Strongly disagree
(5) Disagree
$\odot$ Neutral
(9) Agree
Strongly Agree

4) I prefer to write without the help of a computer.
2t/ Strongly disagree
(:) Disagree
(-) Neutral
(2) Agree
Strongly Agree

5) Writing on the computer is a lot of fun.
25/ Strongly disagree
(D) Disagrce
- Neutral
(3) Agree
(9) Strongly Agree

6) When I write on the computers my stories are poor.
는 Strongly disagree
(8) Disagree
$\odot$ Neutral
(4) Agrec
Strongly Agree 
7) I like to have people read what I write on the computer.
25.) Strongly disagree
(8) Disagree
$(\bullet)$ Neutral
(-) Agree
Strongly Agree

8) If I have the opportunity to write on the computer or to use paper and pencil I choose to write on the computer.
22. Strongly disagree
(2) Disagree
(-) Neutral
(-) Agree
(2) Strongly Agree

9) Computers make me want to write more.

23. Strongly disagree $\odot$ Disagree $\quad($ Neutral $\quad(2)$ Agree $\quad$ (9) Strongly Agree

10) I write less when I use the computer.
is. Strongly disagree
(-) Disagree
$(-)$ Neutral
(P) Agree
(9) Strongly Agree

11) I make more changes in my stories when I write on the computer.
25) Strongly disagree
(2) Disagree
(-) Neutral
(-) Agree
(9) Strongly Agree

12) I like to know that a great number of people can order my stories on the Net.
22. Strongly disagree
$\odot$ Disagree
(-) Neutral
(-) Agree
(9) Strongly Agree

13) Knowing that my work is going to be published or turned into an electronic book motivates me to write.
22. Strongly disagree
(2) Disagree
$(-)$ Neutral
(ن) Agree
(99) Strongly Agree

14) Computers make writing boring.
25. Strongly disagree
(2) Disagree
(-) Neutral

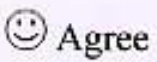
(2) Strongly Agree

15) Writing on the computers is the best part in Mrs. Nedeff's class.

25 Strongly disagree (:) Disagree $\quad(-)$ Neutral ()) Agree (2) Strongly Agree Thank you very much for all your help! 
APPENDIX B:

\section{STUDENTS' INTERVIEW}




\section{Students' Interview}

1) What do you think about writing in English on the computer? Why?

2) Tell me about a story that you have written recently using the help of a computer:

3) How did you use the computer to write the story?

4) How did you feel when writing the story on the computer?

5) What did you like most about writing on the computer?

6) What did you like least about writing on the computer?

7) How would you feel if computers were taken from the Reading and Writing class? Why?

8) How different it would be if in the Reading and Writing class you did not have computers to use? Why?

9) How would you feel if you could only use computers to write?

10) How do you think computers help you in the Reading and Writing class? 
APPENDIX C:

VERA'S INTERVIEW 


\section{Vera's Interview}

1) Would you rather that this interview be confidential or can I attribute the information that will be given in this interview to you in my thesis?

2) What is the role of computers in the "Student as Authors" project?

3) What do you think are the advantages for ESL students of using a computer to write?

4) What do you think is the disadvantages for ESL students of using a computer to write?

5) What do you think are the advantages for native English speakers of using a computer to write?

6) What do you think are the disadvantages for English speakers students of using a computer to write?

7) How important do you consider the computer in the "Student as Authors" project? Why?

8) Do you consider the use of computers as a motivational aspect in the "Student as Authors" Project? Why?

9) How would you describe ESL students' reactions/ attitude when writing on the computer? Could you give me some example?

10) How would you describe native English speaker's reactions/ attitude when writing on the computer? Could you give me some example?

11) How different the project would be if the students did not have access to computers? Do you think that if would interfere directly in the students' motivation to write? Why?

12) What were the major changes in this year "Student as Authors" project?

13) How many classes are evolved in the "Student as Authors" project this year?

14) How did you decide to have the fourth and fifth graders write poems this year?

15) What is the process of the fourth graders to write the poems?

16) How much will the poem book be sold?

17) How much a student makes for writing a book in this school?

18) Can a student still hire an illustrator?

19) Are students in this school year operating a store? What grade is operating it?

20) Are you still doing the accounting? 
APPENDIX D:

\section{PATY'S INTERVIEW}




\section{Paty's Interview}

1) Would you rather that this interview be confidential or can I attribute the information that will be given in this interview to you in my thesis?

2) What is the role of computers in the "Student as Authors" project?

3) What do you think are the advantages for ESL students of using a computer to write?

4) What do you think is the disadvantages for ESL students of using a computer to write?

5) What do you think are the advantages for native English speakers of using a computer to write?

6) What do you think are the disadvantages for English speakers students of using a computer to write?

7) How important do you consider the computer in the "Student as Authors" project? Why?

8) Do you consider the use of computers as a motivational aspect in the "Student as Authors" Project? Why?

9) How would you describe ESL students' reactions/attitude when writing on the computer? Could you give me some example?

10) How would you describe native English speaker's reactions/attitude when writing on the computer? Could you give me some example?

11) How different the project would be if the students did not have access to computers? Do you think that if would interfere directly in the students' motivation to write? Why? 